\title{
ON THE SURFACE CONDENSATION OF STEAM.
}

\author{
BY LT.-Colonel THOMAS ENGLISH.
}

In the course of a series of trials made for the Direct Measurement of Initial Condensation in a Compound Steam-Engine,* the author has been led to the conclusion that the condensation of steam on a metallic surface is in all cases governed by the thermal resistance of the film of water deposited by the condensation of the steam itself. The rate of condensation varies directly as the difference of temperature between the two surfaces of this film, and inversely as its thickness; and there is no difference between the thermal resistance of the surface of the metal and that of its interior substance. The present paper includes an account of the trials referred to, and a comparison of their results with calculations based on the author's conclusions; together with the explanation, by similar calculations, of the results of experiments by other enquirers into the subjects of surface condensation and evaporation.

Engine.-The engine on which these trials were made was built by Messrs. B. Donkin and Co. in 1890, and is in use at Palmer's Ordnance Works, Jarrow. As shown in the general plan, Fig. 1, Plate 20, it consists of a high-pressure and a low-pressure cylinder set horizontally side by side, and connected to cranks at right angles to each other on the shaft, with the fly-wheel between them. The high-pressure cylinder is 20 inches diameter, and the low-pressure $32 \frac{1}{2}$ inches, and the stroke of each is 48 inches.

Valves.-Each cylinder is fitted with separate steam and exhaust valves of the Sulzer kind, the high-pressure steam-valves being

* Previous papers by the author on Condensation in Steam-Engine Cylinder's are printed in the Proceedings, 1887 page 503, 1889 page 641, and 1892 page 198. 
controlled by the governor through trip gear which allows of separate adjustment of the beginning and of the end of the steam admission, Figs. 2 and 3, Plate 21. The valves are all of doublebeat pattern with vertical spindles; the steam valves are on the top of each cylinder at the ends, opening upwards, and the exhaust valves directly below them, also opening upwards. Motion is given to the valve spindles, through levers and connecting rods, by eams on a separate revolving shaft $S$ for each cylinder, parallel to the axis, and connected by mitre wheels to the crank shaft. The cams which lift the steam valves of the low-pressure cylinder are capable of being set so as to vary the point of cut-off. A relief valve $2 \frac{1}{4}$ inches diameter, kept shut by a spiral spring, is fitted at each end of each cylinder.

Jacketing.-Both cylinders are jacketed on the barrel by the working steam, which has to circulate round the cylinder before it enters through the steam valves. The barrel jacket is prolonged six inches beyond each end of the cylinder; and the cylinder ends are further jacketed by cavities cast in them, communicating with the prolongation of the barrel jacket through four holes of half-inch diameter, two at the top and two at the bottom.

Auxiliary Valve-Gear.-The trials are designed to weigh the steam required to fill the clearance at the commencement of each stroke, separately from that which enters the cylinder after the piston begins to move. For this purpose the end of the highpressure cylinder farthest from the crank was selected; and an auxiliary valve-gear, independent of the ordinary steam-admission, was fitted, by which the steam to fill the clearance is supplied from a separate boiler of an 8-HP. portable engine, through a 2-inch pipe $37 \frac{1}{2}$ feet long and lagged throughout, to a double-bent valve $V$,

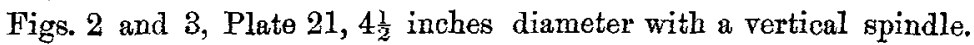
This valve is fitted as close as possible to the cylinder, and opens into it through the seating of the relief valve, which is temporarily removed. At each revolution of the engine the valve spindle is lifted through a bent lever $\mathrm{L}$, by an adjustable cam $\mathrm{C}$ secured to the revolving shaft $\mathbf{S}$ which drives the main valve-gear, as shown in Figs. 2 and 3. This double-bent valve is closed by its own steam 
acting on four square inches of unbalanced area, and aided by an india-rubber spring $R$. In order to give as sharp a cut-off as possible to this auxiliary valve, it is made to lift as much as half an inch by the action of the cam, although a lift of only 0.15 inch gives an opening equal to the area of the 2-inch steam-pipe. The cam is adjusted to open the auxiliary valve at any desired point during the period of compression, and to close on the dead centre; whilst the main steam-valve is adjusted to open at the dead centre, and thus to continue the supply of steam to the cylinder. The combined action of the two valves produces an indicator diagram which cannot be distinguished from the diagram drawn when using the main valve-gear alone, adjusted in the ordinary way.

Measurement of Initial Condensation.-By weighing the amount of water evaporated in the auxiliary boiler for a known number of strokes, it becomes possible by this arrangement to ascertain directly the amount of steam expended per stroke, partly in initial condensation, and partly in increasing the pressure in the clearance from that due to the cushion steam; and by adding to the weight thus found the weight of cushion steam, and deducting the weight of saturated steam required to fill the clearance at the pressure existing when the main valve opens, a direct measure is obtained of the weight condensed in the time required to fill the clearance.

The weight of cushion steam and the weight of saturated steam required to fill the clearance space of 0.782 cubic foot can be readily calculated from measurements of the mean steam-pressure on the indicator diagrams. The indicator gear is arranged either to take diagrams in the ordinary way, or to be conneeted to the crank of the low-pressure cylinder. In the latter case, the pressures which occur at the ends of the stroke are transferred to the middle of the diagram; and the horizontal distances representing on the diagram the motion of the piston near the ends of the stroke are sufficiently elongated to show clearly the intervals between the various changes. Immediately after taking a diagram in this manner, the governor is lifted by hand for a few revolutions, which causes the trip gear to miss 
lifting the main steam-valve: whereby is produced on the same paper a diagram of the steam passing through the auxiliary valve alone. The combined diagram thus obtained, Plates 22 to 30 , is employed to determine a scale for the time occupied in the observed condensation, by measuring on it the horizontal distance between the point corresponding with the moment of admission through the auxiliary valve, and the point at which the two curves diverge. This horizontal distance bears approximately the same proportion to the product of $\pi \times$ total length of diagram, as the time elapsed from the commencement of admission bears to the total time of a revolution. The weight of steam condensed in this time, multiplied by its latent heat, and divided by the area of clearance surface, 13.98 square feet, gives the number of thermal units set free by condensation on each square foot; and the mean rate of condensation per square foot per minute can be determined therefrom, when the actual time occupied in condensation has been calculated.

In order to ascertain accurately the weight of water supplied to the auxiliary boiler, its feed-pump is driven from shafting, and the tub from which it draws its supply is mounted on a one-ton weighing machine. The auxiliary boiler is pumped up while cold to a marked level on the gauge glass; steam is then raised, and all feed-water weighed into the boiler. After the boiler has cooled down again on the conclusion of a trial, sufficient water is either pumped in or taken out to bring the water-level to the same mark on the gauge glass; and the weight thus required is added to or deducted from the weight of feed-water previously observed. A correction, ascertained by trial, of 14 lbs. per hour, is also applied to allow for imperceptible leakage whilst the boiler is under steam.

Results of Trials.-The mean results of each of the trials are detailed in the appended Table 22, lines 1 to 22, omitting those trials in which doubt existed as to the accuracy of any of the measurements. For each trial detailed the indicator diagrams nearest to the mean are shown, both from the low-pressure crank and also the ordinary diagram, and both for the main steam and for the auxiliary-valve steam; these are shown in Plates 22 to 30 . The (continued on page 148.) 
TABLE 22 (continued to page 147).

Results of Trials for direct measurement of

Initial Condensation in a Compound Engine.

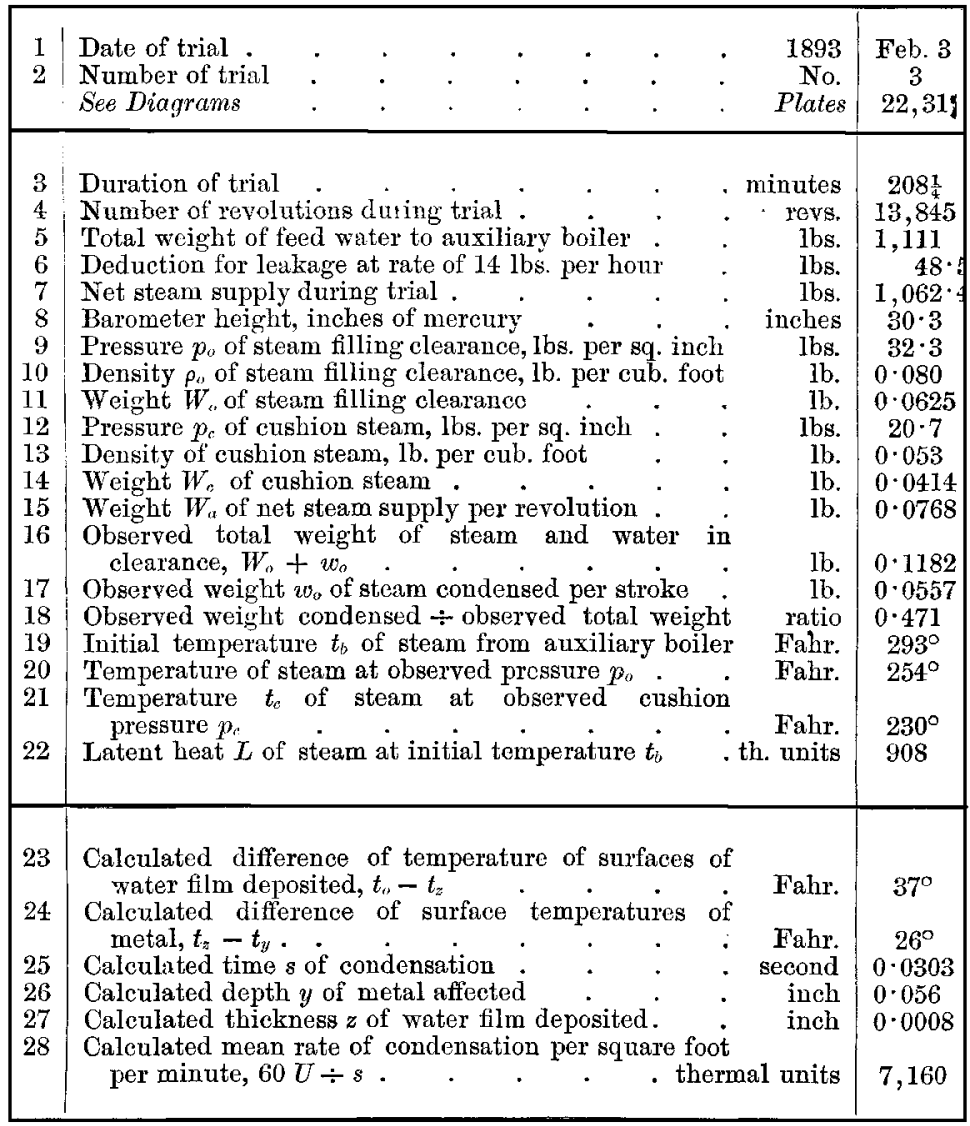


FEB. 1894.

SURFACE CONDENSATION OF STEAM.

(continued on next page) TABLE 22.

Results of Trials for direct measurement of

Initial Condensation in a Compound Engine.

\begin{tabular}{|c|c|c|c|c|c|c|c|c|}
\hline $\begin{array}{c}\text { Feb. } 8 \\
4 \\
22,31\end{array}$ & $\begin{array}{c}\text { Feb. } 21 \\
6 \\
23,32\end{array}$ & $\begin{array}{c}\text { Feb. } 28 \\
7 \\
23,32\end{array}$ & $\begin{array}{c}\text { Mar. } 7 \\
8 \\
24,33\end{array}$ & $\begin{array}{c}\text { Mar. } 14 \\
9 \\
24,33\end{array}$ & $\begin{array}{c}\text { Mar. } 16 \\
10 \\
25,34\end{array}$ & $\begin{array}{c}\text { Mar. } 27 \\
12 \\
25,34\end{array}$ & $\begin{array}{c}\text { Apr. } 13 \\
14 \\
26,35\end{array}$ & $\begin{array}{l}1 \\
2\end{array}$ \\
\hline 212 & 210 & 150 & 150 & 153 & 150 & 150 & 150 & 3 \\
\hline 14,050 & 14,324 & 9,978 & 10,188 & 10,278 & 9,980 & 9,954 & 9,954 & 4 \\
\hline $1,081 \cdot 5$ & 1,003 & $871 \cdot 5$ & 951 & $933 \cdot 5$ & 998 & $956 \cdot 25$ & $965 \cdot 75$ & 5 \\
\hline $49 \cdot 5$ & 49 & 35 & 35 & $35 \cdot 75$ & 35 & 35 & 35 & 6 \\
\hline 982 & 954 & $836 \cdot 5$ & 916 & $897 \cdot 75$ & 963 & $921 \cdot 25$ & $930 \cdot 75$ & 7 \\
\hline $29 \cdot 9$ & $29 \cdot 4$ & $29 \cdot 7$ & $30 \cdot 3$ & $29 \cdot 9$ & $29 \cdot 6$ & $30 \cdot 3$ & $30 \cdot 5$ & 8 \\
\hline $28 \cdot 6$ & $28 \cdot 6$ & $32 \cdot 0$ & $30 \cdot 0$ & $30 \cdot 0$ & $35 \cdot 1$ & 29 & 28 & 9 \\
\hline 0.071 & 0.071 & $0 \cdot 079$ & $0 \cdot 075$ & 0.075 & $0 \cdot 086$ & 0.072 & 0.070 & 10 \\
\hline 0.0555 & $0 \cdot 0555$ & 0.0618 & 0.0586 & $0 \cdot 0586$ & 0.0672 & $0 \cdot 0563$ & 0.0547 & 11 \\
\hline $17 \cdot 3$ & $19 \cdot 2$ & $20 \cdot 9$ & $19 \cdot 3$ & $18 \cdot 7$ & $22 \cdot 2$ & $14 \cdot 3$ & $14 \cdot 3$ & 12 \\
\hline $0 \cdot 045$ & 0.049 & $0 \cdot 054$ & $0 \cdot 049$ & 0.048 & $0 \cdot 056$ & $0 \cdot 038$ & $0 \cdot 038$ & 13 \\
\hline 0.0352 & 0.0383 & 0.0422 & 0.0383 & 0.0375 & 0.0438 & 0.0297 & 0.0297 & 14 \\
\hline $0 \cdot 0699$ & 0.0666 & $0 \cdot 0839$ & 0.0899 & 0.0874 & 0.0965 & 0.0926 & 0.0936 & 15 \\
\hline $0 \cdot 1051$ & $0 \cdot 1049$ & 0.1261 & 0.1282 & 0.1249 & $0 \cdot 1403$ & 0.1223 & 0.1233 & 16 \\
\hline 0.0496 & 0.0494 & 0.0643 & 0.0696 & 0.0663 & 0.0731 & 0.0660 & 0.0686 & 17 \\
\hline 0.472 & 0.471 & 0.510 & 0.543 & 0.531 & 0.521 & 0.540 & 0.556 & 18 \\
\hline $293^{\circ}$ & $293^{\circ}$ & $308^{\circ}$ & $308^{\circ}$ & $308^{\circ}$ & $308^{\circ}$ & $308^{\circ}$ & $308^{\circ}$ & 19 \\
\hline $247^{\circ}$ & $247^{\circ}$ & $254^{\circ}$ & $250^{\circ}$ & $250^{\circ}$ & $259^{\circ}$ & $248^{\circ}$ & $246^{\circ}$ & 20 \\
\hline $220^{\circ}$ & $226^{\circ}$ & $230^{\circ}$ & $226^{\circ}$ & $224^{\circ}$ & $234^{\circ}$ & $211^{\circ}$ & $211^{\circ}$ & 21 \\
\hline 908 & 908 & 897 & 897 & 897 & 897 & 897 & 897 & 22 \\
\hline $45^{\circ}$ & $40^{\circ}$ & $49^{\circ}$ & $52^{\circ}$ & $53^{\circ}$ & $46^{\circ}$ & $64^{\circ}$ & $64^{\circ}$ & 23 \\
\hline $28^{\circ}$ & $27^{\circ}$ & $29^{\circ}$ & $30^{\circ}$ & $31^{\circ}$ & $28^{\circ}$ & $33^{\circ}$ & $\mathbf{3 3}^{\circ}$ & 24 \\
\hline 0.0199 & 0.0221 & 0.0306 & 0.0336 & 0.0295 & 0.0419 & 0.0245 & 0.0265 & 25 \\
\hline 0.045 & 0.048 & 0.056 & 0.059 & 0.055 & 0.066 & 0.050 & 0.052 & 26 \\
\hline 0.0007 & 0.0007 & 0.0010 & 0.0010 & $0 \cdot 0010$ & 0.0010 & $0 \cdot 0010$ & 0.0010 & 27 \\
\hline 9,690 & 8,690 & 8,100 & 7,980 & 8,650 & 6,710 & 10,350 & 9,960 & 28 \\
\hline
\end{tabular}


TABLE 22 (continued from preceding page).

Results of Trials for direct measurement of

Initial Condensation in a Compound Engine.

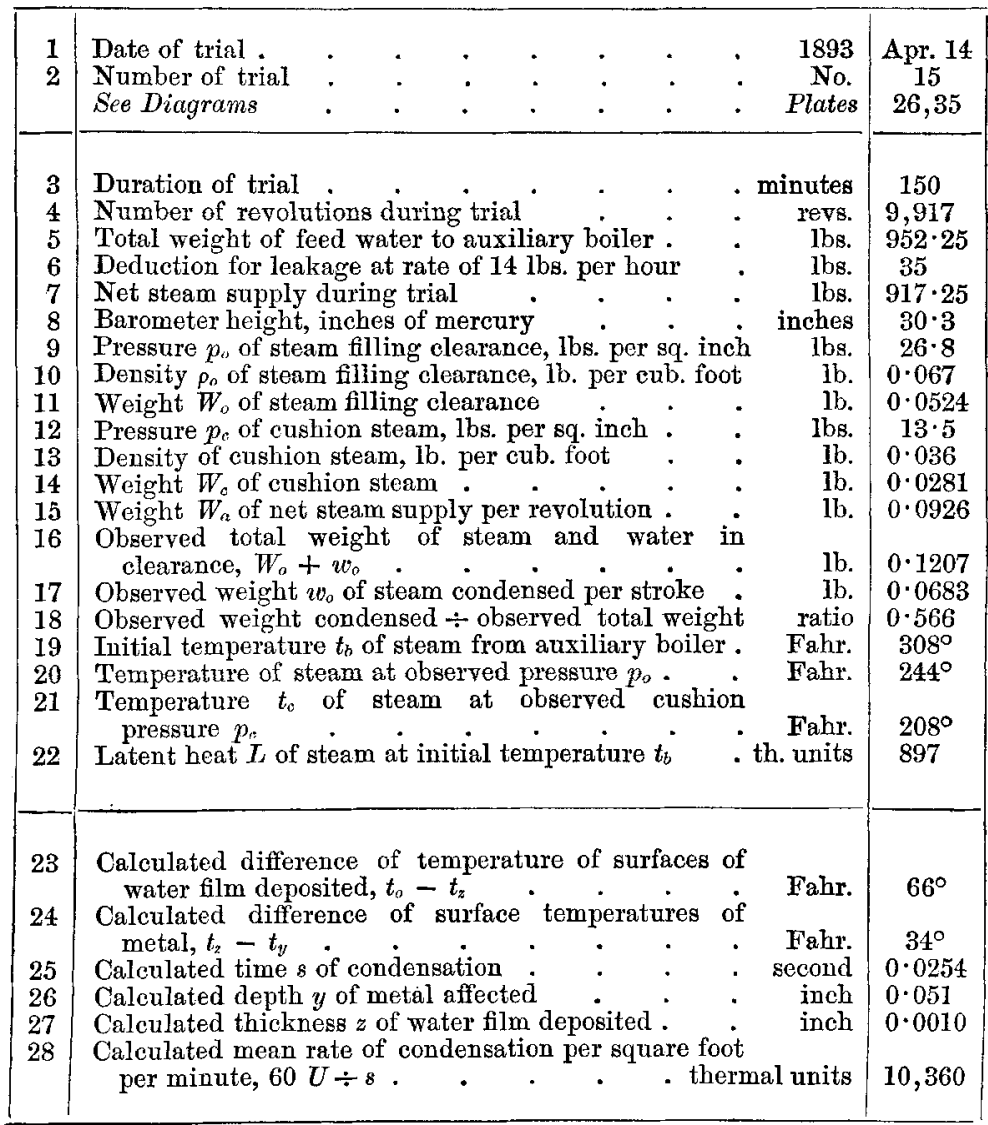


(concluded from page 144) TABLE 22.

Results of Trials for direct measurement of

Initial Condensation in a Compound Engine.

\begin{tabular}{|c|c|c|c|c|c|c|c|c|}
\hline $\begin{array}{c}\text { Apr. } 17 \\
16 \\
27,36\end{array}$ & $\begin{array}{c}\text { Apr. } 18 \\
17 \\
27,36\end{array}$ & $\begin{array}{c}\text { Apr. } 20 \\
18 \\
28,37\end{array}$ & $\begin{array}{c}\text { Apr. } 28 \\
22 \\
28,37\end{array}$ & $\begin{array}{c}\text { Apr. } 29 \\
23 \\
29,38\end{array}$ & $\begin{array}{c}\operatorname{May} 15 \\
29,38\end{array}$ & $\begin{array}{c}\text { May } 25 \\
25 \\
30,39\end{array}$ & $\begin{array}{c}\text { June } 1 \\
26 \\
30,39\end{array}$ & $\begin{array}{l}1 \\
2\end{array}$ \\
\hline 150 & $\mathbf{I} 50$ & 150 & 150 & 150 & 150 & 150 & 150 & 3 \\
\hline 10,158 & 9,969 & 9,884 & 9,946 & 9,871 & 4,561 & 4,850 & 4,804 & 4 \\
\hline 905 & $927 \cdot 25$ & 910 & 1,006 & $990 \cdot 25$ & $668 \cdot 25$ & $686 \cdot 50$ & 723 & 5 \\
\hline 35 & 35 & 35 & 35 & 35 & 35 & 35 & 35 & 6 \\
\hline 870 & $892 \cdot 25$ & 875 & 971 & $955 \cdot 25$ & $633 \cdot 25$ & $651 \cdot 50$ & 688 & 7 \\
\hline $30 \cdot 4$ & $30 \cdot 3$ & $30 \cdot 2$ & $30 \cdot 1$ & $30 \cdot 1$ & $30 \cdot 2$ & $29 \cdot 9$ & $29 \cdot 9$ & 8 \\
\hline $30 \cdot \overline{3}$ & $29 \cdot 1$ & $27 \cdot 3$ & $30 \cdot 1$ & $29 \cdot 5$ & $38 \cdot \mathfrak{I}$ & $28 \cdot 9$ & $35 \cdot 4$ & 9 \\
\hline $0 \cdot 076$ & 0.073 & $0 \cdot 069$ & 0.076 & 0.074 & 0.094 & 0.072 & 0.087 & 10 \\
\hline 0.0594 & 0.0571 & 0.0540 & 0.0594 & 0.0578 & 0.0735 & 0.0563 & $0 \cdot 0682$ & 11 \\
\hline $20 \cdot 9$ & $16 \cdot 7$ & $14 \cdot 3$ & $16 \cdot 7$ & $15 \cdot 5$ & $13 \cdot 6$ & $10 \cdot 3$ & $13 \cdot 3$ & 12 \\
\hline 0.054 & 0.043 & 0.038 & $0 \cdot 043$ & 0.040 & 0.036 & $0 \cdot 027$ & 0.035 & 13 \\
\hline 0.0422 & 0.0336 & 0.0297 & 0.0336 & 0.0313 & 0.0281 & 0.0211 & 0.0274 & 14 \\
\hline 0.0856 & 0.0896 & 0.0886 & 0.0976 & 0.0968 & $0 \cdot 1388$ & 0.1343 & $0 \cdot 1432$ & 15 \\
\hline 0.1278 & 0.1232 & $0 \cdot 1183$ & $0 \cdot 1312$ & $0 \cdot 1281$ & $0 \cdot 1669$ & 0.7554 & $0 \cdot 1706$ & 16 \\
\hline 0.0684 & 0.0661 & 0.0643 & 0.0718 & 0.0703 & 0.0934 & 0.0991 & $0 \cdot 1024$ & 17 \\
\hline 0.535 & 0.536 & 0.543 & 0.547 & 0.549 & $0 \cdot 560$ & $0 \cdot 637$ & 0.602 & 18 \\
\hline $308^{\circ}$ & $308^{\circ}$ & $308^{\circ}$ & $308^{\circ}$ & $308^{\circ}$ & $308^{\circ}$ & $308^{\circ}$ & $308^{\circ}$ & 19 \\
\hline $251^{\circ}$ & $249^{\circ}$ & $245^{\circ}$ & $251^{\circ}$ & $249^{\circ}$ & $264^{\circ}$ & $248^{\circ}$ & $260^{\circ}$ & 20 \\
\hline $230^{\circ}$ & $218^{\circ}$ & $211^{\circ}$ & $218^{\circ}$ & $215^{\circ}$ & $208^{\circ}$ & $195^{\circ}$ & $207^{\circ}$ & 21 \\
\hline 897 & 897 & 897 & 897 & 897 & 897 & 897 & 897 & 22 \\
\hline $49^{\circ}$ & $58^{\circ}$ & $64^{\circ}$ & $58^{\circ}$ & $60^{\circ}$ & $66^{\circ}$ & $76^{\circ}$ & $67^{\circ}$ & 23 \\
\hline $29^{\circ}$ & $32^{\circ}$ & $33^{\circ}$ & $32^{\circ}$ & $33^{\circ}$ & $34^{\circ}$ & $37^{\circ}$ & $34^{\circ}$ & 24 \\
\hline $0 \cdot 0346$ & 0.0271 & 0.0233 & $0 \cdot 0319$ & $0 \cdot 0293$ & 0.0474 & 0.0461 & 0.0564 & 25 \\
\hline $0 \cdot 059$ & $0 \cdot 053$ & 0.049 & 0.057 & $0 \cdot 055$ & 0.070 & 0.069 & 0.076 & 26 \\
\hline 0.0010 & $0 \cdot 0010$ & 0.0010 & $0 \cdot 0011$ & $0 \cdot 0011$ & $0 \cdot 0014$ & 0.0015 & $0 \cdot 0015$ & 27 \\
\hline 7,610 & 9,400 & 10,620 & 8,650 & 9,220 & 7,570 & 8,270 & 6,980 & 28 \\
\hline
\end{tabular}


ordinates marked on each pair indicate simultaneous angular positions in the revolution of the crank-shaft; but the two diagrams in each pair, not being taken simultaneously, do not necessarily correspond exactly.

In line 9 of the Table, the pressure $p_{0}$ of steam filling the clearance space is that marked in diagram 3, Plate 22, measured from zero to the point at which the diagram representing the steam admitted through the auxiliary valve alone diverges from that representing the steam admitted through both valves; for it is evident that, even if the auxiliary valve were not closed at this point, no more steam could enter through it against the increasing pressure of the steam admitted through the main valve.

In line 12, the pressure $p_{c}$ of cushion steam is measured from zero, as shown in diagram 3, Plate 22 , to the point at which the compression curve changes its direction owing to the admission of the steam through the auxiliary valve.

Each trial in which the conditions have been varied has been repeated a sufficient number of times to ensure that similar results, within reasonable limits of error of observation, would follow a further repetition. The trials show that an amount of heat may be set free which will correspond with a mean rate of initial condensation of from 6,700 to 10,600 thermal units per square foot per minute.

If it be assumed that the clearance surface is dry before admission, the possible rate of condensation will vary directly as the difference between the temperatures of the two surfaces of the film of water deposited by the condensation itself, and inversely as its thickness; the rate must therefore be exceedingly rapid at first, and immediately diminish. The amount of heat observed to be set free may be accounted for as being absorbed by the metal, following generally the method of calculation adopted by Professor Cotterill in "The Steam Engine," (second edition, page 278); but it is necessary to change the supposition (page 284) that the surface temperature of the metal on the admission of steam follows a harmonic cycle, into a supposition that it is the same as that of the adjoining surface of the water film. It is also necessary to make some supposition 
as to the variation of temperature in the interior of the metal; and the author has chosen the assumption of a constant difference between the surface temperature and that of the metal immediately beyond the surface layer affected, as probably near the truth during the time of condensation. It will be shown that on these assumptions the results from the indicator diagrams can be brought into satisfactory accordance with ealculation based on the known laws of conductivity.

The amount of heat available per square foot is measured by the weight of the film of water deposited, multiplied by its latent heat at the temperature at which condensation commences. The small amount of heat set free by the cooling of the film is neglected; and therefore the flow of heat at any instant through the film is taken to be equal to the flow into the metal at the same time. The heat passing into the metal is considered to be entirely absorbed in raising the temperature of the surface layer, under the condition that the difference between the surface temperature and the temperature of any point in the surface layer which is receiving heat will vary with the depth of the point beneath the surface. This implies that the thermal gradient through the surface layer at any instant has a uniform inclination, but that this inclination decreases throughout from instant to instant. Similarly the difference between the temperature of the surface of the film of water next the steam, and the temperature of any point within the film, is assumed to vary with the depth measured from the surface next the steam.

The auxiliary-boiler pressure was kept at 60 lbs. absolute per square inch in trials Nos. 3,4 , and 6 , and at 75 lbs. absolute in the remainder; and the initial temperature $t_{b}$ of the steam filling the clearance (line 19) has been taken as that due to the auxiliary-boiler pressure. If $t_{z}$ be the temperature of the common surface of the film of water and of the metal at any time; and if $t_{y}$ be the temperature at the same time of the metal immediately beyond the interior boundary of the surface layer of thickness $y$, which has received heat up to this time; and if $t_{o}$ be the temperature to which the steam has fallen, owing to the condensation:- then $t_{o}-t_{z}$ will be the difference of temperature between the two surfaces of the film of water, and $t_{z}-t_{y}$ 
will be the difference of surface temperatures produced in the metal. Taking the average results of experiments on conductivity in iron from Cotterill (page 278), it has been found that, if $F$ be the flow of heat through the surface per square foot per second,

$$
F=\frac{7 \cdot 5}{60} \times \frac{d\left(t_{z}-t\right)}{d y}
$$

where $y$ is measured in inches. Hence if $U$ be the number of thermal units which have passed through a square foot of the surface in $s$ seconds, with the assumptions made

$$
\begin{gathered}
\frac{d\left(t_{z}-t\right)}{d y}=\frac{t_{z}-t_{y}}{y} \\
\text { and } \frac{d U}{d s}=F=0.125 \times \frac{t_{z}-t_{y}}{y} . . .
\end{gathered}
$$

Taking the conductivity of water as 0.01 that of iron, if $z$ be the thickness measured in inches of the film of water which has been deposited, the flow of heat through it

$$
\begin{aligned}
\frac{d U}{d s}=F & =0.01 \times \frac{7 \cdot 5}{60} \times \frac{d\left(t_{o}-t\right)}{d z} \\
& =0.00125 \times \frac{t_{0}-t_{z}}{z} . . .
\end{aligned}
$$

For cast-iron weighing $450 \mathrm{lbs}$. per cubic foot, or $37 \cdot 5 \mathrm{lbs}$. per each inch in thickness of a plate one foot square, with a specific heat of $0 \cdot 13$,

$$
\begin{aligned}
\frac{d U}{d y} & =37.5 \times 0.13 \times \text { mean rise of temperature } \\
& =4.875 \times \frac{t_{z}-t_{y}}{2} \cdot . \quad . \quad . \quad . \quad . \quad .
\end{aligned}
$$

Also if $w$ is the weight of a cubic foot of water in pounds, $\frac{1}{12} w z$ will be the weight in pounds per square foot of the film of condensed water, and

$$
U=\frac{1}{12} w z L \quad \cdot \quad \cdot \quad \cdot \quad \cdot .
$$

where $L$ is the latent heat corresponding to the temperature $t_{b}$.

From equations (1) and (3)

and

$$
\frac{d s}{d y}=19 \cdot 5 y
$$

$$
y=0.32 \sqrt{s} \text {. . . . . }
$$


or the depth of metal affected varies as the square root of the time, and the conditions determining the flow of heat in the metal will be satisfied by an equation of the form

$$
\frac{y}{0 \cdot 32 \sqrt{s}}=\frac{t_{z}-t}{t_{z}-t_{y}} .
$$

From equations (1) (2) and (5)

From (1) (4) and (5)

$$
t_{o}-t_{z}=\frac{100}{0.32}\left(t_{z}-t_{y}\right) \frac{z}{\sqrt{8}} \cdot \text {. . }
$$

$$
\frac{1}{12} w L \frac{d z}{d s}=\frac{d U}{d s}=\frac{0 \cdot 125}{0.32} \times \frac{t_{z}-t_{y}}{\sqrt{s^{-}}}
$$

Hence $\quad \frac{1}{12} w L z=\frac{0 \cdot 125}{0 \cdot 32} \times\left(t_{z}-t_{y}\right) \times 2 \sqrt{s}$

$$
\text { or } z=\frac{3}{0 \cdot 32} \frac{\left(t_{z}-t_{y}\right)}{w L} \sqrt{s} \quad . \quad . \quad . \quad .
$$

From (4) and (7)

$\left.\begin{array}{l}\text { Mean rate of condensation } \\ \text { in thermal units per } \\ \text { square foot per minute }\end{array}\right\}=\frac{60 U}{s}=46 \cdot 85 \frac{\left(t_{z}-t_{y}\right)}{\sqrt{s}}$.

From (6) and (7) $t_{o}-t_{z}=2925 \frac{\left(t_{z}-t_{y}\right)^{2}}{w L}$,

$$
\text { or } t_{o}-t_{y}=t_{z}-t_{y}+2925 \frac{\left(t_{z}-t_{y}\right)^{2}}{w L} \text {. }
$$

From given values of $t_{b}$ and $t_{c}$, to which the values of $t_{o}$ and $t_{y}$ at the commencement of condensation are assumed respectively to be equal, the calculated value of the rise of surface temperature of the metal $\left(t_{z}-t_{y}\right)$ can be found by equation (9), and is given in line 24 of the table; and this being known, the values of $y$, $z$, and $V$ can be determined for successive increments of $s$.

To connect these equations with the observed results, and determine the value of $s$ for each trial: if $w_{0}$ be the weight of the film of water which has been deposited up to any time $s$,

$$
w_{o}=\frac{1}{12} w \times \text { square feet of surface } \times z
$$

and by equation (7)

$$
w_{o}=10.92 \frac{t_{z}-t_{y}}{L} \sqrt{s} \quad . \quad . \quad . \quad . \quad .
$$


The value of $s$ corresponding to the observed value of $w_{o}$ can be obtained from this equation; and a curve can be drawn whose abscissæ represent a scale of time, and ordinates a scale of density, which will give the diminution of density of the remaining steam, caused by condensation, for successive increments of $s$. By the help of a table of the properties of steam, this curve can be transformed into one whose abscissw represent a scale of time, and ordinates a scale of temperature. If the combined indicator diagram, in which the pressures have been converted to the corresponding temperatures, be drawn to the same scales, the condensation temperature curve can be connected with them by placing its origin at a point on the time scale determined by the following considerations. The rate of rise of mean temperature of the steam in the clearance after the admission of the auxiliary-boiler steam must depend upon the velocity of the latter through the steam pipe, and this is taken for calculation at 800 feet per second. During admission the steam in the clearance space must at the same instant vary in pressure and temperature from point to point; but the steam which is in contact with the walls must have the same temperature as the surface of the metal. A curve of rise in mean temperature of steam during admission, starting from the temperature $t_{c}$, and a corresponding curve of surface temperature according to equation (9), can therefore be drawn to determine the time at which the temperature of the surface of the metal reaches the highest calculated value of $t_{z}$, when the condensation of the steam from the auxiliary boiler begins. These curves are shown in the diagrams, Plates 31 to 39 , by the full line $\mathrm{ZO}$ of calculated mean steam temperature during admission, and by the dotted line ZZZ of calculated surface temperature. The line $\mathrm{OO}$ is the calculated steam temperature during condensation; and the length included between these letters is the portion of the curve to which the tabulated values of $s, y, z$, and $U$ refer. III are the curves from the indicator diagrams in Plates 22 to $30, \mathrm{~B}$ B the line of auxiliary-boiler temperature, and A A the main-boiler temperature. During tho period of condensation nothing approaching the auxiliary-boiler pressure is recorded by the indicator, which shows only an apparentiy irregular curve. 
An approximate calculation of the rate of initial condensation in the cylinder of a brass indicator shows that the fall of temperature of the steam must take place at a much quicker rate than in the engine cylinder; and it is probable that the changes of pressure take place so rapidly that, owing to inertia, the indicator piston has not time to follow them, and that therefore the momentary duration of the boiler pressure cannot be recorded by it. Further experiments however are required to determine this point; and all that can be said with certainty at present is that pressure must exist to fill the clearance, which is not shown on the indicator diagrams.

In trials 3 to 12 the jacket space in the cylinder cover was filled from the barrel-jacket, and drained back into it. In trials 14 and 22, it was filled from the barrel-jacket, and separately drained through a trap. In trials 15 to 18 and 23 to 26 , the communications were plugged, so that no steam entered the cover-jacket. Trials 14 and 15 were witnessed by Mr. Bryan Donkin, who kindly verified the measurements relating to them.

Evaporation of Water by Surface Condensation of Steam.-Similar equations to the foregoing can be employed to represent the results of the process of evaporating water by the surface condensation of steam on a metallic plate. During steady ebullition it is probable that no film, either of water or of steam, can permanently adhere to the surface from which the evaporation is taking place; but that minute particles of water are periodically brought into actual contact with the metal, and thereby changed into steam. The momentary rate of flow of heat which results from this contact will be extremely rapid, as compared with the rate of transmission of heat by conduction throngh a measurable thickness of metal; and the change of any one of the particles of water into steam, whatever may be the nature of the process, will probably absorb the whole available heat from a small area of an exceedingly thin surface layer of metal. The steam produced will then act as a non-conducting medium, until an amount of heat equal to that abstracted by evaporation is returned to the surface layer by conduction through the metal. Ebullition may therefore be considered as an intermittent process, consisting of a 
series of cycles, in any one of which the distribution of heat will, at the moment of evaporation of a particle of water, be the reverse of that at the first instant of the process of condensation, when the rate of flow of heat is so rapid as to make the transmission virtually instantaneous.

Let $t_{e}$ be the temperature of evaporation; $t_{y}$ the temperature of the evaporating surface common to the water and the metal; and $t_{z}$ the temperature of the interior of the metal. Then for cast iron

$$
\Delta U=37 \cdot 5 \times 0 \cdot 13 \times\left(t_{y}-t_{e}\right) \times \Delta y
$$

will be the heat instantaneously abstracted by evaporation from one square foot of the surface layer of which $\Delta y$ is the thickness; and

$$
\Delta U=37.5 \times 0.13 \times \frac{t_{z}-t_{y}}{2} \times \Delta y
$$

will be the heat gradually restored by conduction to the same surface layer.

$$
\text { Hence } t_{z}-t_{y}=2\left(t_{y}-t_{e}^{\prime}\right) \text {. }
$$

By a similar equation to (9) $t_{y}-t_{e}=\frac{2925}{w L}\left(t_{z}-t_{y}\right)^{2}$,

$$
\text { and therefore } t_{y}-t_{e}=\frac{w L}{117 \overline{0} \overline{0}} .
$$

Comparison of Calculated with Observed results.-The results of experiments on the transmission of heat from a steam-jacket through cast-iron cylinder liners of varying thickness, which were communicated to the Institution by Mr. Morison at the meeting in October 1892, page 485, will enable a test of these conclusions to be made. In those experiments, during steady evaporation, the thickness of the film of condensed water remaining on the outer surface of the liner must evidently be constant, and would be limited by the formation of drops. This limiting thickness the author considers for rough vertical cast-iron surfaces will probably be near 0.005 inch, and assuming it to be 0.0051 inch, $y$ being taken as the thickness of the liner, and $t_{b}$ as the temperature of the jacket steam, the equations representing the steady flow $F$ of heat will be

$$
F=\frac{d U}{d s}=\frac{0.00125\left(t_{b}-t_{z}\right)}{0.0051}=\frac{0.125\left(t_{b}-t_{y}\right)}{y+0.51}
$$


In this case $t_{e}=212^{\circ}$, and from equation (11)

$$
\begin{aligned}
& t_{y}=212^{\circ}+\frac{966 w}{11700}=217^{\circ} ; \\
& \text { hence } F=\frac{t_{b}-217^{\circ}}{8 y+4.08}
\end{aligned}
$$

will give the number of thermal units passing through the liner per square foot per second. The weight of water evaporated per hour can be calculated from this equation, when the temperature to which the foed-water is raised by the escaping heat is known. This temperature is not given in Mr. Morison's communication; but assuming it to be $100^{\circ}$, then

Lbs. of water evaporated $\}=\frac{3,600 \times \text { sq. feet internal surface } \times F}{966^{\circ}+210^{\circ}-100^{\circ}}$.

From this equation the calculated results are obtained which are given in Table 23 in juxtaposition with the corresponding actual results observed in Mr. Morison's experiments. In the diagram, Plate 40 , are shown by dots the actual results obtained; and the inclined straight lines are drawn in accordance with calculation from equations (12) and (13). The diagram is also furnished with a scale of thickness of metal, by which the relation between the number of pounds evaporated and the temperature of the condensing steam can be seen for any thickness of liner up to one inch. The results shown in the table and diagram not only indieate the remarkable accuracy of Mr. Morison's experiments, but also confirm the values of the coefficients of conductivity for water and cast-iron, as well as

* A direct experiment shows that at a temperature of $60^{\circ} \mathrm{Fahr}$. the thickners of the film of water which will remain on a vertical plane surface of cast-iron rough from the sand is $0.0041 \mathrm{inch}$, and that this thickness is reduced to 0.0027 inch when the surface is roughly planed, and to 0.0023 inch when it is polished. If the cylindrical shape of the liner is taken into account by means of the formula $F=0.125\left(t_{b}-t_{y}\right) \div\left(R \log _{2} \frac{R}{r}+100 z\right)$, where $R$ and $r$ are the outer and inner radii, the value 0.004 inch for $z$ will give a near approximation to Mr. Morison's results. To determine from this formula the weight of water evaporated per hour, it would be necessary to know what proportion of the outer surface of the liner is effectively employed in the transmission of heat to the water; and recent experiments by Mr. B. Donkin and the anthor show that it is extremely difficult to ascertain this proportion accurately. 
TABLE 23.-Transmission of Heat from Steam-Jacket

through Cast-Lron Cylinder-Liners of varying thickness.

External Surface of Liner 11 inches diameter, 3.84 square feet. Internal Surface of Liner:-

$9 \cdot 19$ inches diameter, $3 \cdot 007$ square feet.
$10 \cdot 16$
s)
"s
$3 \cdot 324$
$10 \cdot 62$
,
,
$3 \cdot 477$, ,

\begin{tabular}{|c|c|c|c|c|c|c|c|c|c|}
\hline \multirow{2}{*}{$\begin{array}{c}\text { Pounds of Water } \\
\text { Evaporated per hour } \\
\text { at } 212^{\circ} \text { Fahr. } \\
\text { Plate } 40 .\end{array}$} & \multirow{2}{*}{$\begin{array}{c}\text { Thickness } \\
\text { of } \\
\text { metal. }\end{array}$} & \multicolumn{8}{|c|}{$\begin{array}{l}\text { Steam Pressure in Jacket, pounds per square inch above atmosphere; } \\
\text { and corresponding Temperature Fahr. }\end{array}$} \\
\hline & & $\begin{array}{l}10 \mathrm{Ibs} \\
240 \cdot 1^{\circ}\end{array}$ & $\begin{array}{l}20 \mathrm{lbs} . \\
259 \cdot 3^{\circ}\end{array}$ & $\begin{array}{l}30 \mathrm{lbs} . \\
274 \cdot 4^{\circ}\end{array}$ & $\begin{array}{l}40 \mathrm{lbs} . \\
287 \cdot 1^{\circ}\end{array}$ & $\begin{array}{l}50 \mathrm{lbs} . \\
298 \cdot 0^{\circ}\end{array}$ & $\begin{array}{l}60 \mathrm{lbs} . \\
307 \cdot 5^{\circ}\end{array}$ & $\begin{array}{l}70 \mathrm{lbs} . \\
316 \cdot 1^{\circ}\end{array}$ & $\begin{array}{l}80 \mathrm{lbs} \\
324 \cdot 1^{\circ}\end{array}$ \\
\hline $\begin{array}{l}\text { Observed } \\
\text { Calculated }\end{array}$ & 0.90 & $\begin{array}{l}\text { Lbs. } \\
20 \frac{1}{2} \\
20 \cdot 6\end{array}$ & $\begin{array}{l}\mathrm{Lbs} . \\
37 \frac{3}{4} \\
\mathbf{3 7} \cdot \mathbf{7}\end{array}$ & $\begin{array}{l}\text { Lbs. } \\
51 \\
51 \cdot 1\end{array}$ & $\begin{array}{l}\text { Lbs. } \\
62 \frac{1}{4} \\
62 \cdot 3\end{array}$ & $\begin{array}{l}\text { Lbs. } \\
72 \\
72 \cdot 1\end{array}$ & $\begin{array}{l}\text { Lbs. } \\
80 \frac{1}{4} \\
80 \cdot 5\end{array}$ & $\begin{array}{l}\text { Lbs. } \\
88 \\
88 \cdot 2\end{array}$ & $\begin{array}{l}\text { Lbs. } \\
95 \\
95 \cdot 3\end{array}$ \\
\hline $\begin{array}{l}\text { Observed } \\
\text { Calculated }\end{array}$ & $0 \cdot 42$ & $\begin{array}{l}35 \\
34 \cdot 5\end{array}$ & $\begin{array}{c}63 \\
63 \cdot 2\end{array}$ & $84 \frac{3}{4}$. & $\begin{array}{c}102 \frac{1}{4} \\
104 \cdot 5\end{array}$ & $\begin{array}{c}119 \\
120 \cdot 8\end{array}$ & $\begin{array}{c}133 \\
135 \cdot 0\end{array}$ & $\begin{array}{c}145 \frac{1}{2} \\
147 \cdot 9\end{array}$ & $\begin{array}{c}157 \\
159 \cdot 8\end{array}$ \\
\hline $\begin{array}{l}\text { Observed } \\
\text { Calculated }\end{array}$ & $0 \cdot 19$ & $\begin{array}{l}47 \frac{1}{2} \\
47 \cdot 9\end{array}$ & $\begin{array}{l}87 \frac{1}{2} \\
87 \cdot 7\end{array}$ & $\begin{array}{c}119 \\
119 \cdot 0\end{array}$ & $\begin{array}{c}145 \frac{1}{4} \\
145 \cdot 3\end{array}$ & $\begin{array}{c}168 \\
167 \cdot 9\end{array}$ & $\begin{array}{c}188 \\
187 \cdot 6\end{array}$ & $\begin{array}{c}206 \\
205 \cdot 5\end{array}$ & $\begin{array}{c}222 \\
222 \cdot 1\end{array}$ \\
\hline $\begin{array}{c}\text { Calculated Temperature } \\
\text { of exterior surface } \\
\text { of metal, } t_{z}\end{array}$ & $\begin{array}{l}0.90 \\
0.42 \\
0.19\end{array}$ & $\begin{array}{l}231 \cdot 7^{\circ} \\
227 \cdot 4^{\circ} \\
223 \cdot 3^{\circ}\end{array}$ & $\begin{array}{l}244 \cdot 0^{\circ} \\
236 \cdot 1^{\circ} \\
228 \cdot 5^{\circ}\end{array}$ & $\begin{array}{l}253 \cdot 6^{\circ} \\
242 \cdot 9^{\circ} \\
232 \cdot 6^{\circ}\end{array}$ & $\begin{array}{l}261 \cdot 7^{\circ} \\
248 \cdot 7^{\circ} \\
236 \cdot 0^{\circ}\end{array}$ & $\begin{array}{l}268 \cdot 7^{\circ} \\
253 \cdot 6^{\circ} \\
239 \cdot 0^{\circ}\end{array}$ & $\begin{array}{l}274 \cdot 8^{\circ} \\
257 \cdot 9^{\circ} \\
241 \cdot 6^{\circ}\end{array}$ & $\begin{array}{l}280 \cdot 3^{\circ} \\
261 \cdot 8^{\circ} \\
243 \cdot 9^{\circ}\end{array}$ & $\begin{array}{l}285 \cdot 3^{\circ} \\
265 \cdot 4^{\circ} \\
246 \cdot 1^{\circ}\end{array}$ \\
\hline
\end{tabular}


the view which the author has adopted, that there is no specific surface-resistance in cast-iron to the entrance or egress of heat.

Steam Condensation in Surface Condenser.-The weight of steam which can be condensed on a metallic surface, and the corresponding rise in temperature of circulating water, may also be similarly calculated. There is ample and trustworthy experimental evidence to show that a flow of heat through a tube or plate can readily be produced, which, although considerably less than when ebullition takes place, is far in excess of any that can be accounted for by conduction through water, or by convection. It is therefore probable that the heat is in the first instance absorbed by the evaporation of portions of a thin film of water, of which one surface momentarily adheres to the metal, whilst the other surface flows with the circulating water; and that the steam thus produced is immediately recondensed, giving up its heat to the surrounding water. Let $c$ be the weight of circulating water, in pounds per second, passing over a square foot of the surface, and $v$ its velocity in feet per second; then the mean velocity of the adherent film will be $\frac{v}{2}$; and let $x$ be its thickness in inches. Let $t_{i}$ be the initial and $t_{f}$ the final temperature of the circulating water; and as before, let $t_{b}$ be the temperature of the steam supply; $t_{z}$ the temperature of the surface of the metal next the steam, and $t_{y}$ the temperature of the surface next the circulating water; $z$ the thickness of the film of condensed water remaining on the surface next the steam. Then if the metallic surface be that of a brass tube, through which the circulating water flows, of thickness $y$, and with a coefficient of conductivity 0.25 , the equations representing the flow of heat $F_{i}$ per square foot per second at the entrance of the circulating water into the tube will be

$$
\begin{gathered}
F_{i}=0.00125 \times \frac{t_{b}-t_{z}}{z}=0.250 \times \frac{t_{z}-t_{y}}{y} \\
=0.00125 \times \frac{t_{y}-t_{i}}{x}=\frac{62 \cdot 5}{12} \times L \frac{v}{2} \\
\text { from which }\left(t_{b}-t_{y}\right)^{2}=0.0521(200 z+y)^{2}\left(t_{y}-t_{i}\right) L v \\
\text { and } F_{i}=0.0571 \sqrt{\left(t_{y}-t_{i}\right) L v .}
\end{gathered}
$$


TABLE 24,-Steam Condensation in Surface Condenser.

\begin{tabular}{|c|c|c|c|c|c|c|c|}
\hline \multirow{2}{*}{\multicolumn{2}{|c|}{$\begin{array}{l}\text { Position of Tube, vertical or horizontal } \\
\text { Number of experiment }\end{array}$}} & \multicolumn{3}{|c|}{ Tube Vertical. } & \multicolumn{3}{|c|}{ Tube Horizontal. } \\
\hline & & 1 & 2 & 3 & 4 & 5 & 6 \\
\hline $\begin{array}{l}\text { Weight o of circulating water per square foot per second } \\
\text { Velocity } v \text { of circulating water, feet per second. } \\
\text { Latent heat } L \text { of evaporation of eirculating water per lb. }\end{array}$ & $\begin{array}{l}\text { lb. } \\
\text { th. units }\end{array}$ & $\begin{array}{l}0 \cdot 1830 \\
1 \cdot 35 \\
1026\end{array}$ & $\begin{array}{l}0 \cdot 6312 \\
4 \cdot 63 \\
1052\end{array}$ & $\begin{array}{l}0 \cdot 8845 \\
6 \cdot 50 \\
1056\end{array}$ & $\begin{array}{l}0 \cdot 1758 \\
1 \cdot 30 \\
1017\end{array}$ & $\begin{array}{l}0 \cdot 6958 \\
\mathbf{5} \cdot 12 \\
1045\end{array}$ & $\begin{array}{l}0 \cdot 9418 \\
6 \cdot 92 \\
1051\end{array}$ \\
\hline $\begin{array}{l}\text { At Entrance. } \\
\text { Difference of temperature between water and steam, } t_{b}-t_{i} \\
\text { Difference of temperatures in circulating water, } t_{y}-t_{i} \\
\text { Flow } F_{i} \text { of heat per square foot per second }\end{array}$ & $\begin{array}{r}\text { Fahr. } \\
\text { Fahr. } \\
\text { th. uxits }\end{array}$ & $\begin{array}{l}197^{\circ} \\
75 \cdot 5^{\circ} \\
18 \cdot 5\end{array}$ & $\begin{array}{l}197^{\circ} \\
37^{\circ} \\
24 \cdot 3\end{array}$ & $\begin{array}{l}198^{\circ} \\
29^{\circ} \\
25 \cdot 5\end{array}$ & $\begin{array}{l}195 \cdot 2^{\circ} \\
112^{\circ} \\
22 \cdot 0\end{array}$ & $\begin{array}{l}195^{\circ} \\
66^{\circ} \\
33 \cdot 9\end{array}$ & $\begin{array}{c}196^{\circ} \\
57^{\circ} \\
36 \cdot 8\end{array}$ \\
\hline $\begin{array}{l}\text { At Exit. } \\
\text { Flow } F_{f} \text { of heat per square foot per second } \\
\text { Rise of temperature of circulating water, } t_{f}-t_{i} . \\
\text { Difference of temperatures in circulating water, } t_{y}-\dot{t_{f}} \\
\text { Difference of temperatures in metal, } t_{z}-t_{y} \\
\text { Difference of temperatures in condensed steam, } t_{b}-t_{z}\end{array}$ & $\begin{array}{l}\text { th. units } \\
\text { Fahr. } \\
\text { Fahr. } \\
\text { Fahr. } \\
\text { Fahr. }\end{array}$ & $\begin{array}{l}12 \cdot 5 \\
79 \cdot 5^{\circ} \\
35 \cdot 0^{\circ} \\
2 \cdot 5^{\circ} \\
80 \cdot 0^{\circ}\end{array}$ & $\begin{array}{r}20 \cdot 6 \\
34 \cdot 5^{\circ} \\
26 \cdot 5^{\circ} \\
4 \cdot 0^{\circ} \\
132 \cdot 0^{\circ}\end{array}$ & $\begin{array}{r}22 \cdot 5 \\
26 \cdot 5^{\circ} \\
23 \cdot 0^{\circ} \\
4 \cdot 5^{\circ} \\
1.44 \cdot 0^{\circ}\end{array}$ & $\begin{array}{l}14 \cdot 0 \\
95 \cdot 0^{\circ} \\
46 \cdot 0^{\circ} \\
3 \cdot 0^{\circ} \\
51 \cdot 0^{\circ}\end{array}$ & $\begin{array}{r}28 \cdot 1 \\
43 \cdot 0^{\circ} \\
45 \cdot 5^{\circ} \\
5 \cdot 5^{\circ} \\
101 \cdot 0^{\circ}\end{array}$ & $\begin{array}{r}31 \cdot 5 \\
35 \cdot 0^{\circ} \\
42 \cdot 0^{\circ} \\
6 \cdot 0^{\circ} \\
113 \cdot 0^{\circ}\end{array}$ \\
\hline Final Temperature $t_{f}$ of Circulating Water $\left\{\begin{array}{l}\text { Observed } \\
\text { Calculated }\end{array}\right.$ & Fahr. & $\begin{array}{l}140 \cdot 0^{\circ} \\
137 \cdot 5^{\circ}\end{array}$ & $\begin{array}{l}93 \cdot 5^{\circ} \\
92 \cdot 5^{\circ}\end{array}$ & $\begin{array}{l}85 \cdot 0^{\circ} \\
84 \cdot 5^{\circ}\end{array}$ & $\begin{array}{l}165 \cdot 0^{\circ} \\
153 \cdot 0^{\circ}\end{array}$ & $\begin{array}{l}101 \cdot 0^{\circ} \\
101 \cdot 0^{\circ}\end{array}$ & $\begin{array}{l}94 \cdot 5^{\circ} \\
93 \cdot 0^{\circ}\end{array}$ \\
\hline Steam Condensed per square foot per hour $\left\{\begin{array}{l}\text { Observed } \\
\text { Caleulated }\end{array}\right.$ & $\begin{array}{l}\text { lbs. } \\
\text { lbs. }\end{array}$ & $\begin{array}{l}52 \cdot 32 \\
53 \cdot 4\end{array}$ & $\begin{array}{l}78 \cdot 18 \\
78 \cdot 4\end{array}$ & $\begin{array}{l}84 \cdot 34 \\
84 \cdot 2\end{array}$ & $\begin{array}{l}67 \cdot 8 \\
62 \cdot 5\end{array}$ & $\begin{array}{l}104 \cdot 6 \\
109 \cdot 5\end{array}$ & $\begin{array}{l}121 \cdot 3 \\
120 \cdot 3\end{array}$ \\
\hline
\end{tabular}


The rise of temperature of the circulating water, as it passes along the tube, will reduce the flow of heat, and the diminution of flow probably varies as the square root of the time; on this supposition, if $F_{f}$ be the flow of heat per square foot per second at the exit of the circulating water from tho tube,

$$
\begin{gathered}
t_{f}-t_{i}=\frac{F_{i}}{c}-\frac{2}{3} \frac{F_{i}-F_{f}}{c}=\frac{F_{i}+2 F_{f}}{3 c} ; \text { and } \\
F_{f}=t_{b}-t_{i}-\frac{F_{i}}{3 c}-\left(t_{y}-t_{f}\right) \div\left(800 z+4 y+\frac{2}{3 c}\right)=0.0571 \sqrt{\left(t_{y}-t_{f}\right) L v}
\end{gathered}
$$

from which the values of $t_{f}$ and $F_{f}$ can be determined.

The weight of steam condensed per square foot per hour will be

$$
3,600 \times \frac{F_{i}+2 F_{f}}{3} \div\left(L+\frac{t_{b}-t_{z}}{2}\right)
$$

Comparison of Calculated with Observed results.-A comparison of these calculations with actual results is shown in Table 24, for experiments on surface condensation made by Mr. B. G. Nichol, and given in "Engineering," 10 December 1875, pages 449-51. In these experiments with a brass tube $\frac{3}{4}$ inch diameter and $65 \frac{1}{8}$ inches long, $y=0.049$ inch; $t_{i}=58^{\circ}, t_{b}=255^{\circ}$ approximately, and the values of $c$ and $v$ are known. It is necessary to assume the value of $z$, which is taken as 0.008 inch when the tube was vertical, and 0.0045 inch when horizontal. The latent heat of evaporation $L$ is taken for the circulating water as corresponding with the temperature $t_{i}+\frac{F_{f}}{c}$, and for the condensed steam as corresponding with $t_{b}$. 
Fig. 1. Arrangement of Experimental Apparatus.

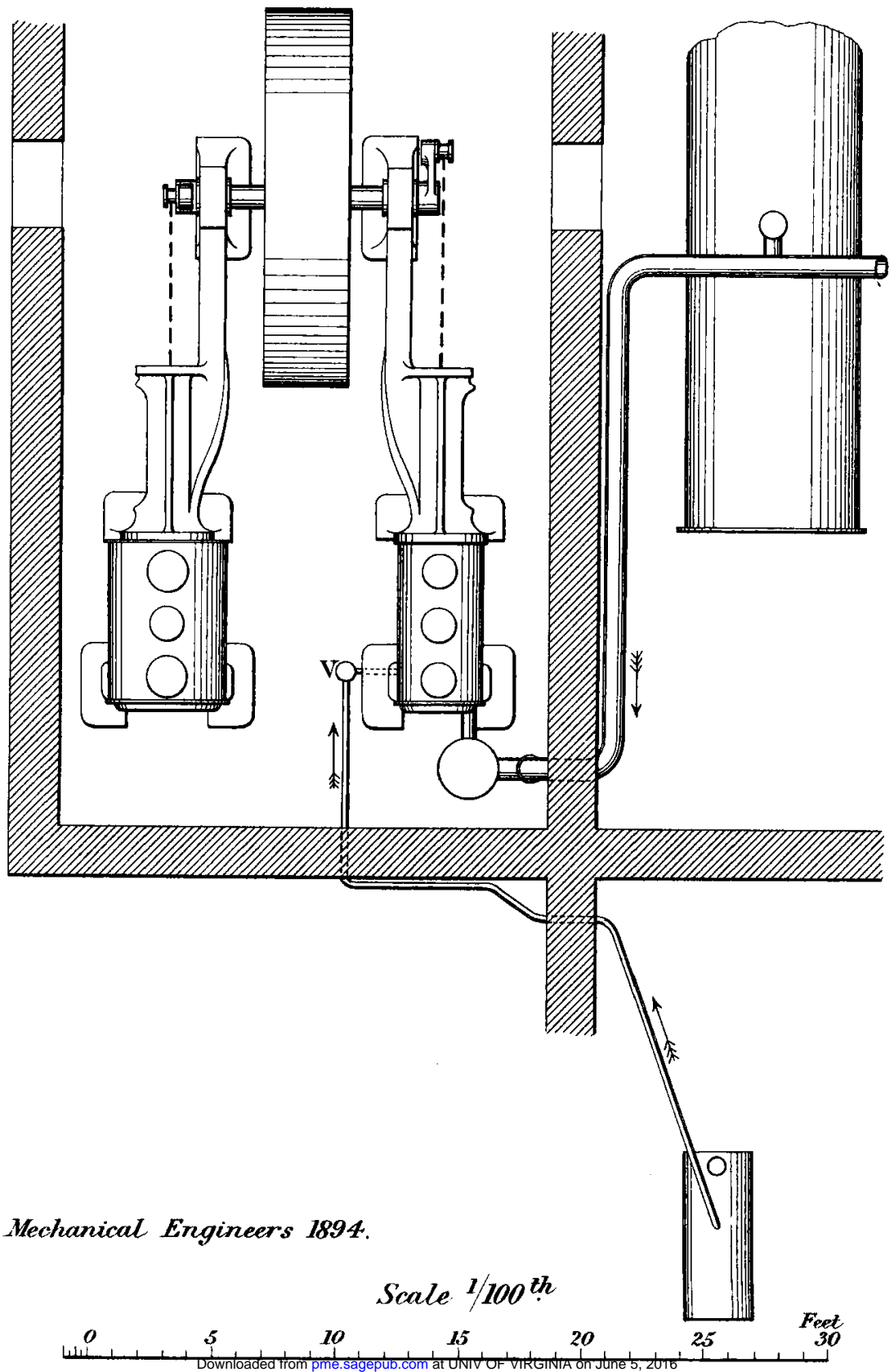




\section{Ausiliary Valve Gear.}

Fig: 2. Plan.

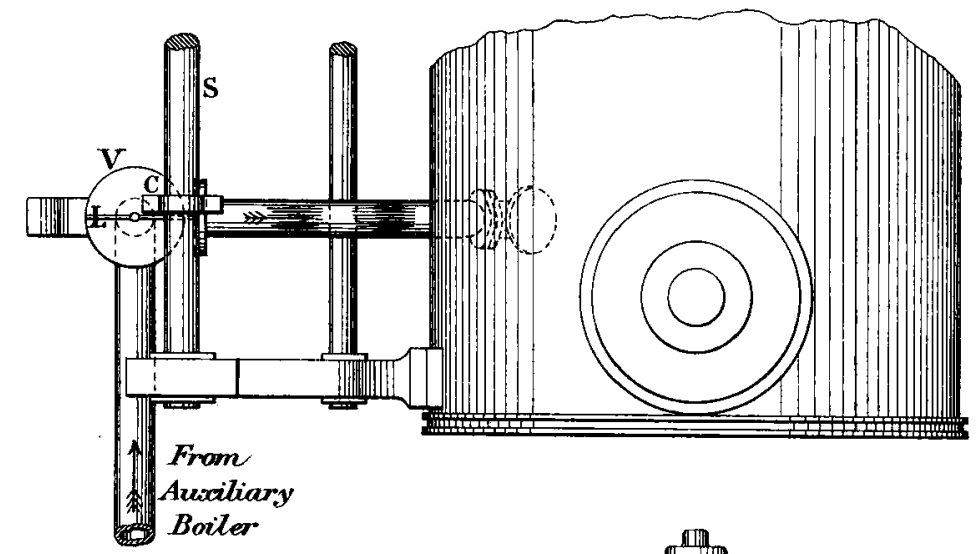

Fig. 3. End Elevation.

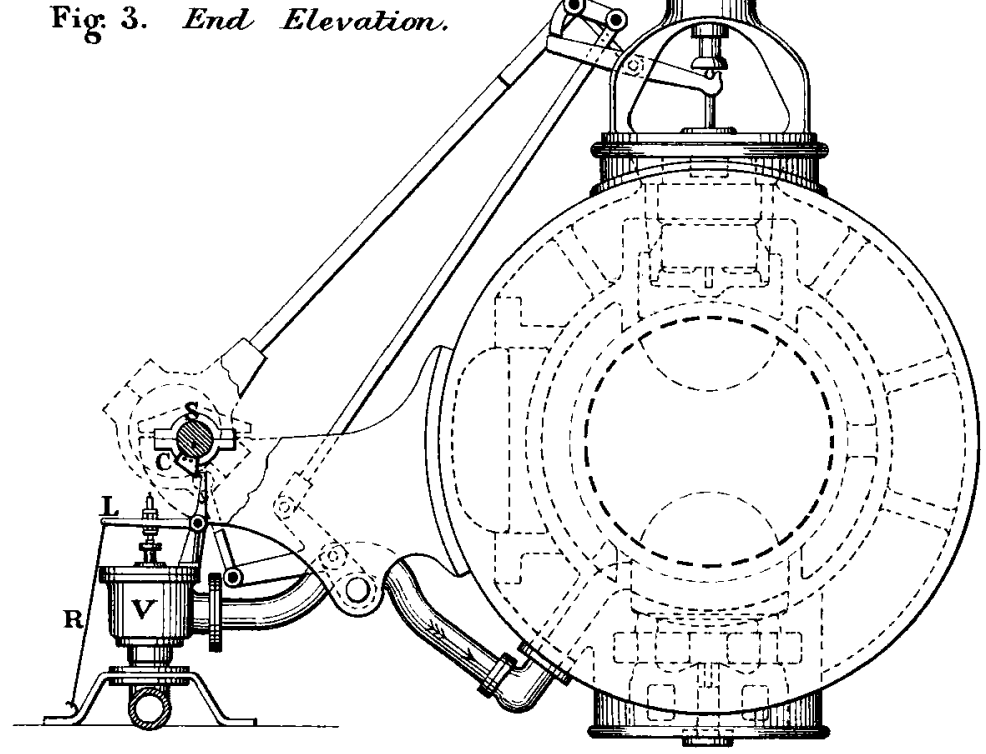

Mechaniand Engineers 1894.

Scale 1/20th

Ins. 12

1

2

3

4 
Bessure

persyuare inch

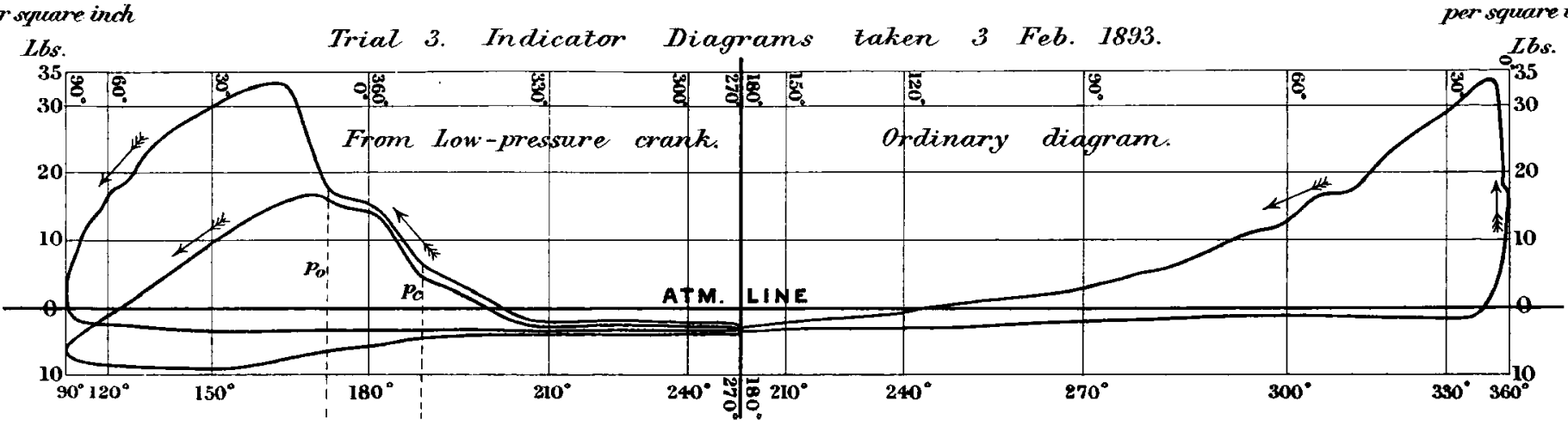
35

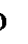

Plate 22.

Pressure
per square inch square inch

Lbs.

Trial 4. Indicator Diagrams taken 8 Feb. 1893.

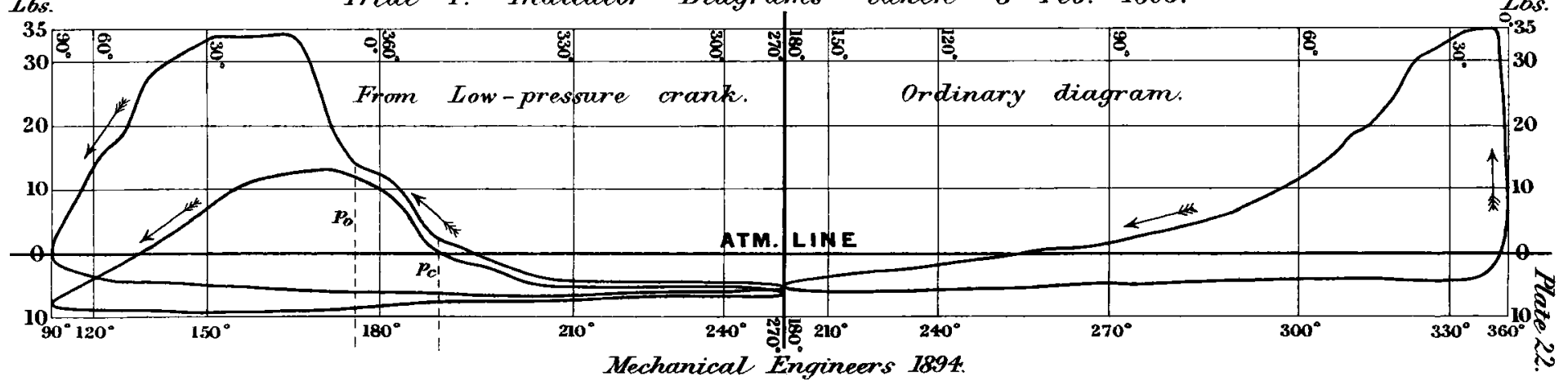


INITIAL CONDENSATION.

Plate 23.

Pressure

persquare inct

Zbs.

Trial 6. Indicator Diagrams zaken 21 Feb. 1893.
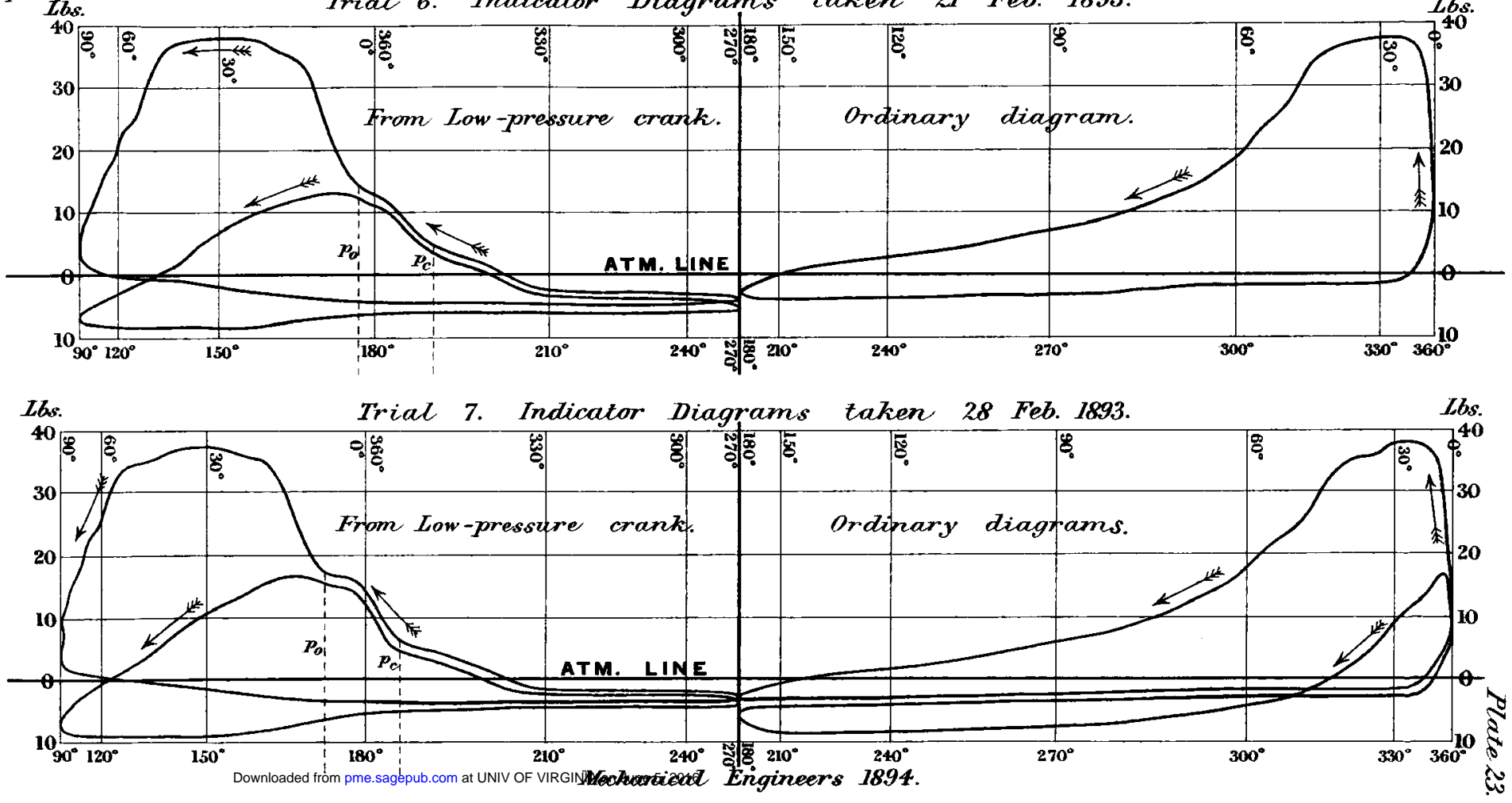
Trial 8. Indicator Diagrams taken 7 March 1893.

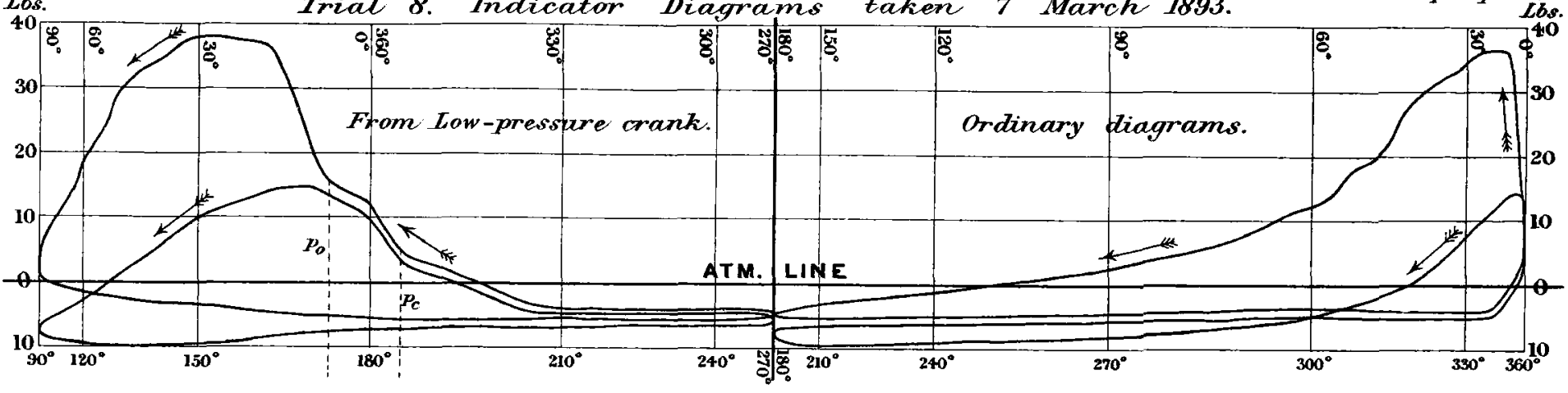

Lbs.

Trial 9. Indicator Diagrams Zaken 14 March 1893.

Lbs.

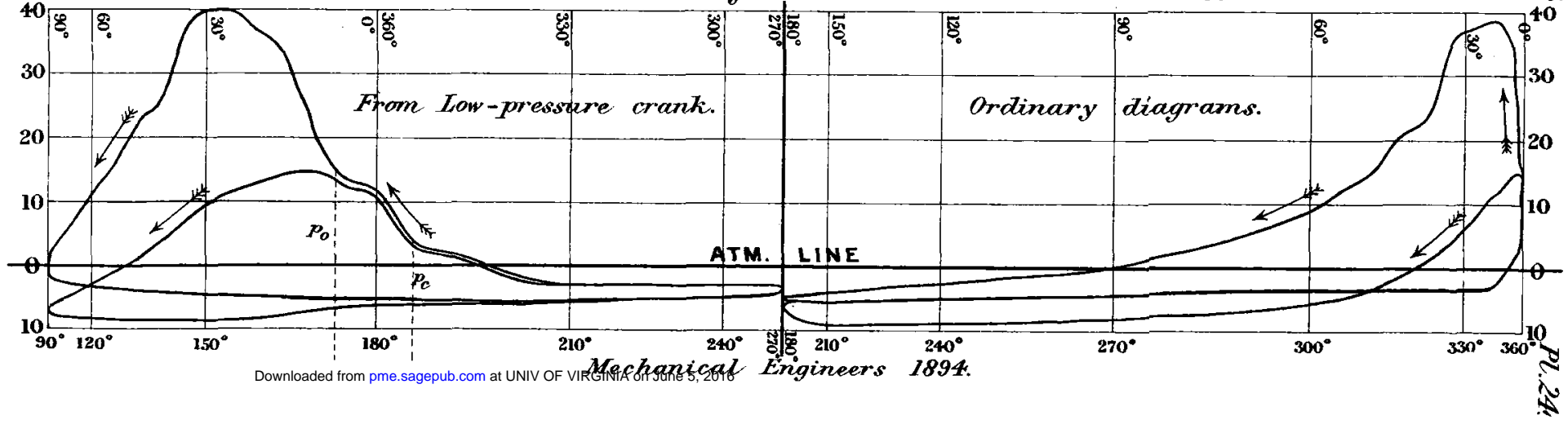




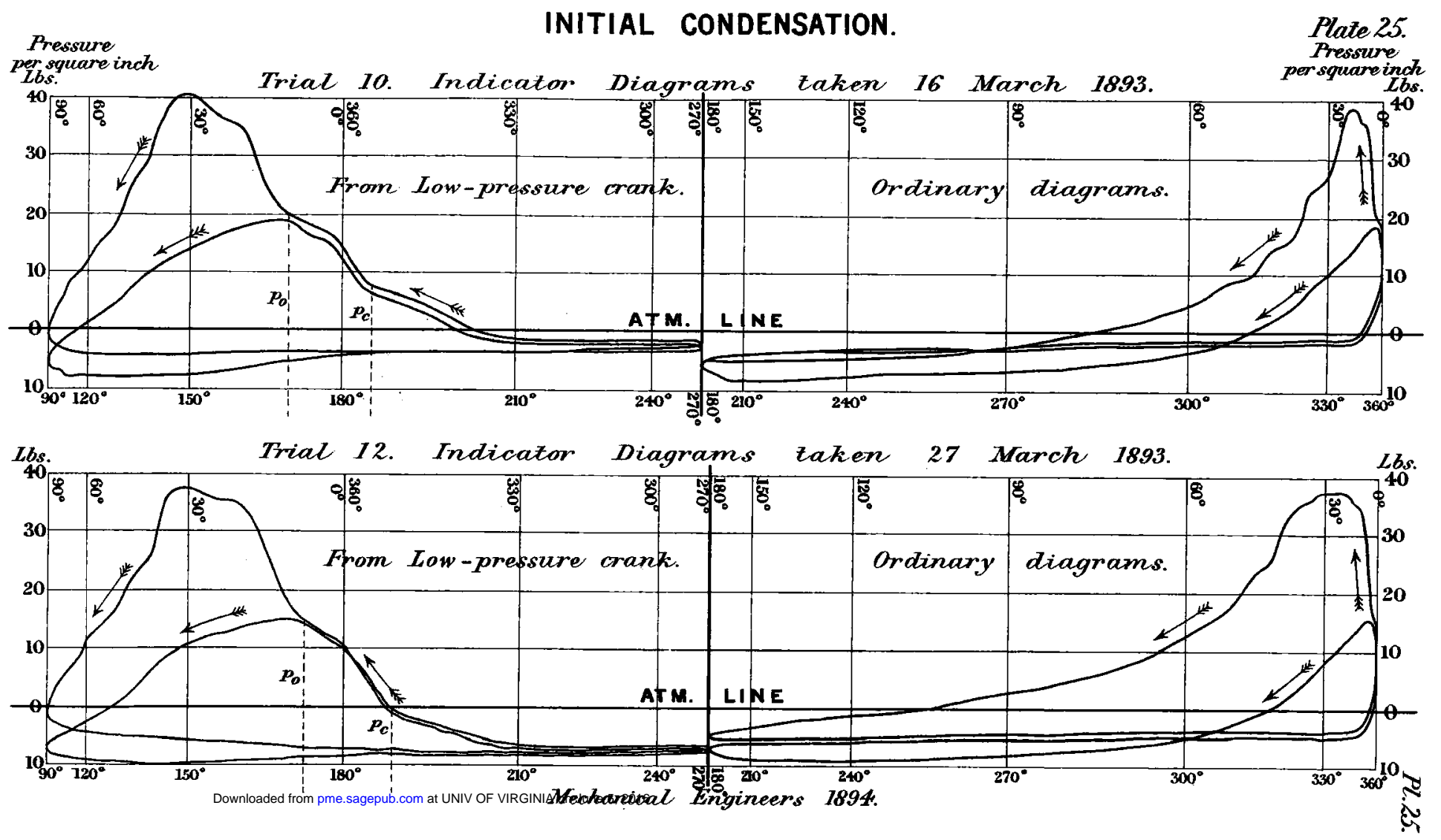


INITIAL CONDENSATION.

Pressure

Pressure
Per square inch

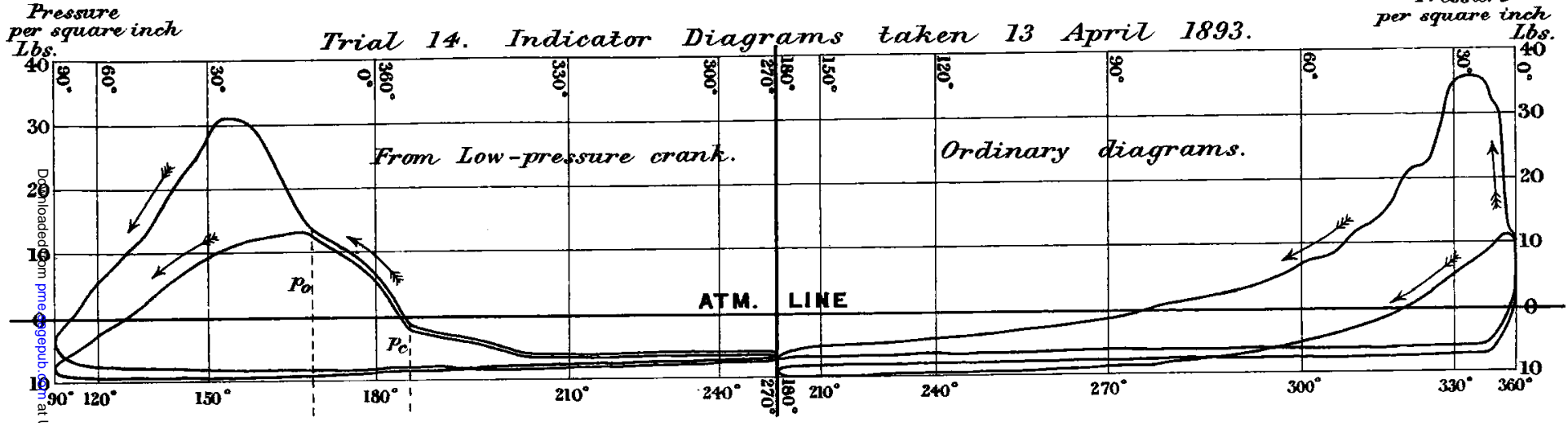

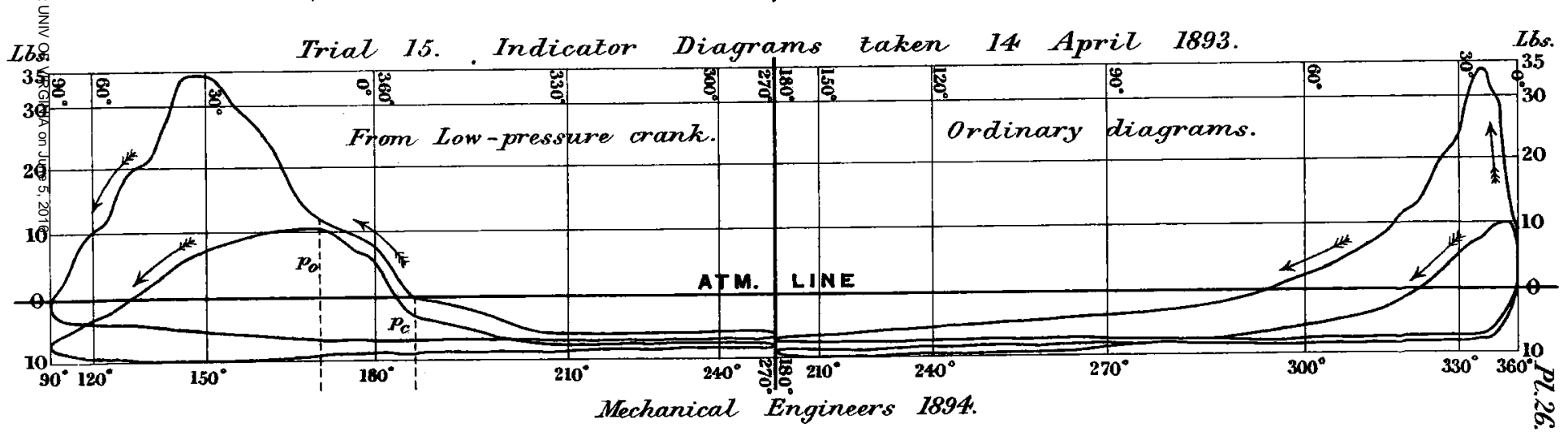


INITIAL CONDENSATION.

Plate 27.

Pressure

per square inch

Lbs.

Trial 16

Aressure

per squareinch

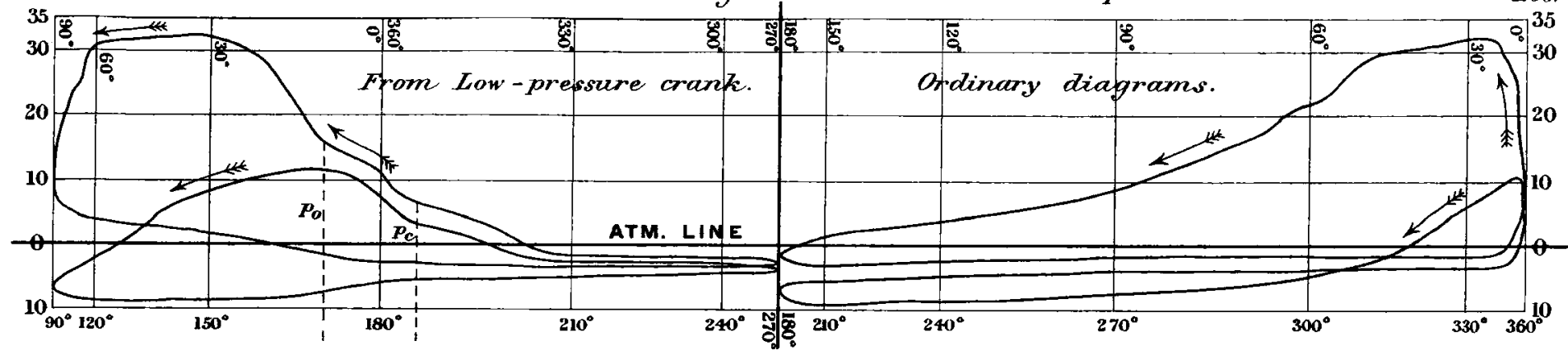

Lbs. Trial 17 . Trdicator Diagrams taken 18 April $1893 . \quad$ Lbs.

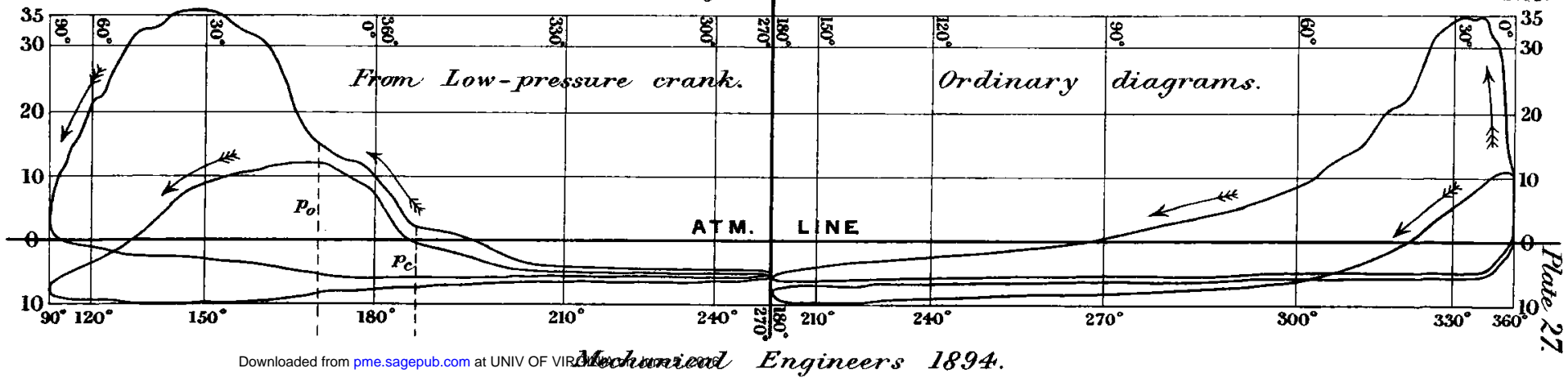

Downloaded from pme.sagepub.com at UNIV OF VIRdhechereacead Engineers 1894 
INITIAL CONDENSATION.

Pressure

per square inch

Lbs.
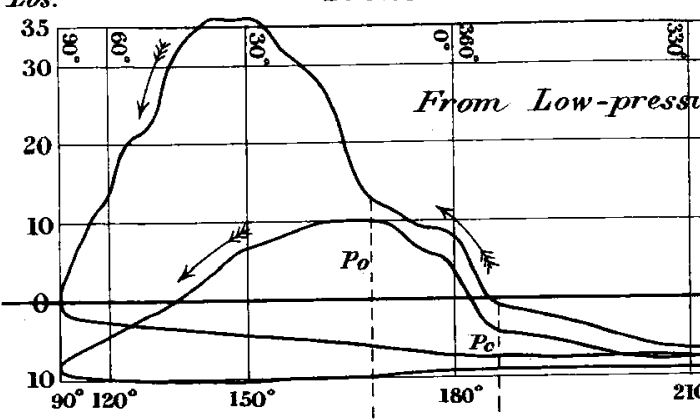

Firm Low-pressure crank.

10

Po

$L b s$.

Trial 22. Indicator Diagrams taken 28 April 1893.

Plate 28

Pressure

per square inch

Trial 18. Indicator Diagrams taken 20 April 1893.

Lbs.

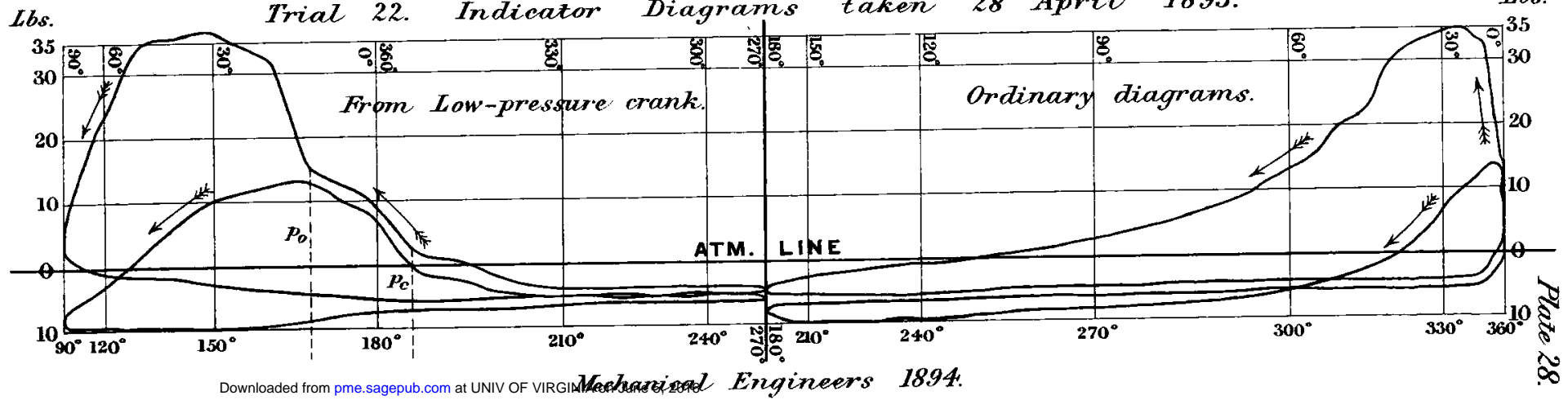

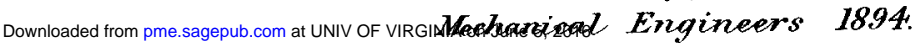


Lbs.

Trial 23. Indicalor

Diagrams

taken

29 April

1893.

Pressitre

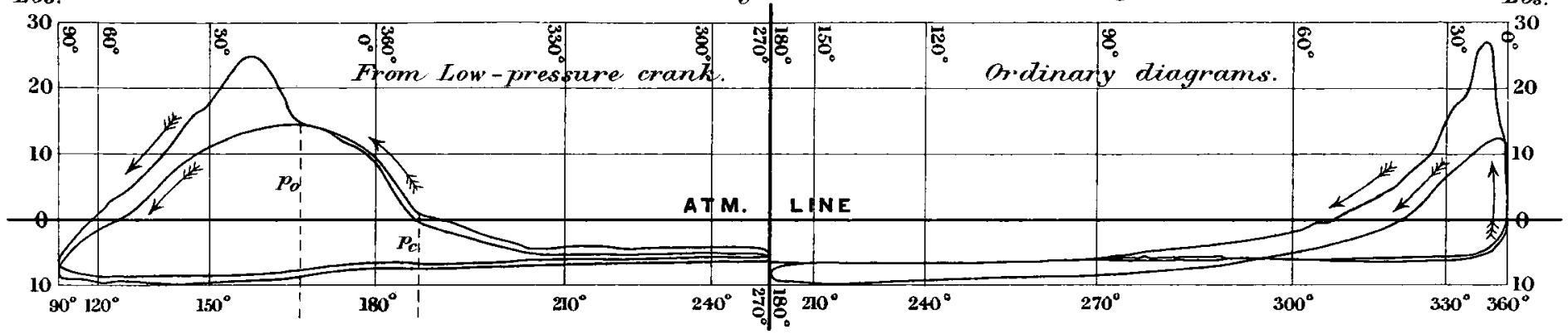

$L b_{s}$. per square inch $90^{\circ} 120^{\circ}$

$150^{\circ}$

Tial 24. Indicazor Diagrams taken 15 May 1893

Trial 24. Indicator Diagrams zaken 15 May 1893.

$L b s$. Lbs:

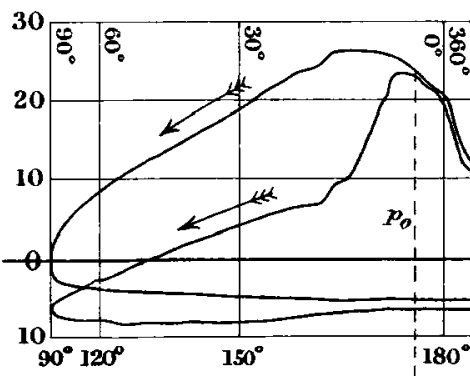

From Low-pressure conet.

Ordinary diagrams. $[8$ ATM. LINE

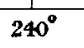

ㄱํㅇ: 210

$240^{\circ}$

$270^{\circ}$

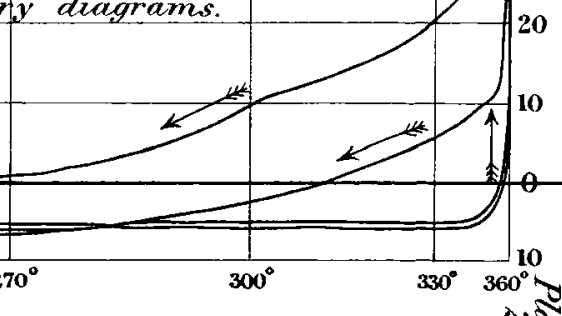


INITIAL CONDENSATION.

Pressure
per square inch
Plate 30

Pressure.

per square inch

Lbs. Trial 25. Indicator Diagrams taken 25 May 1893.

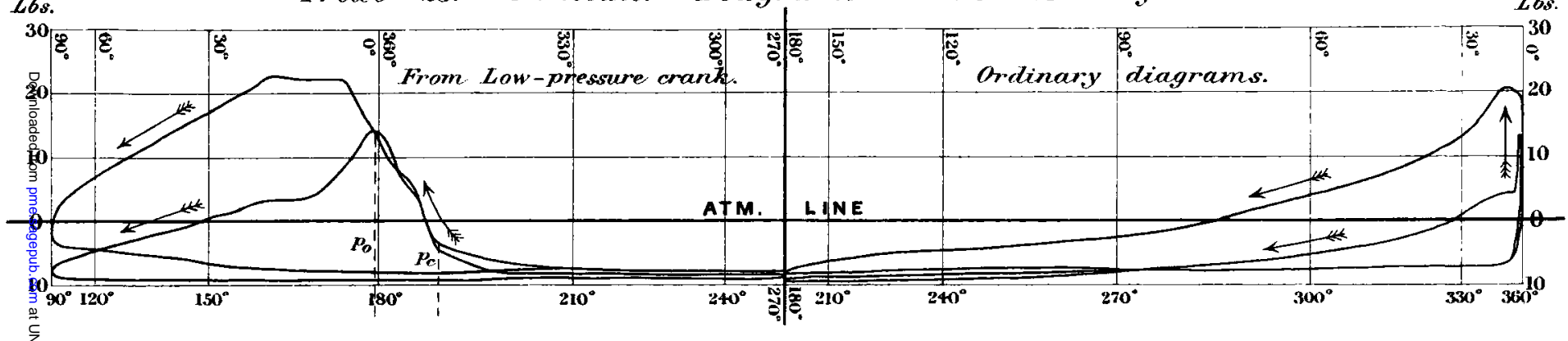

Trial 26. Indicator Diagrams taken I June 1893.

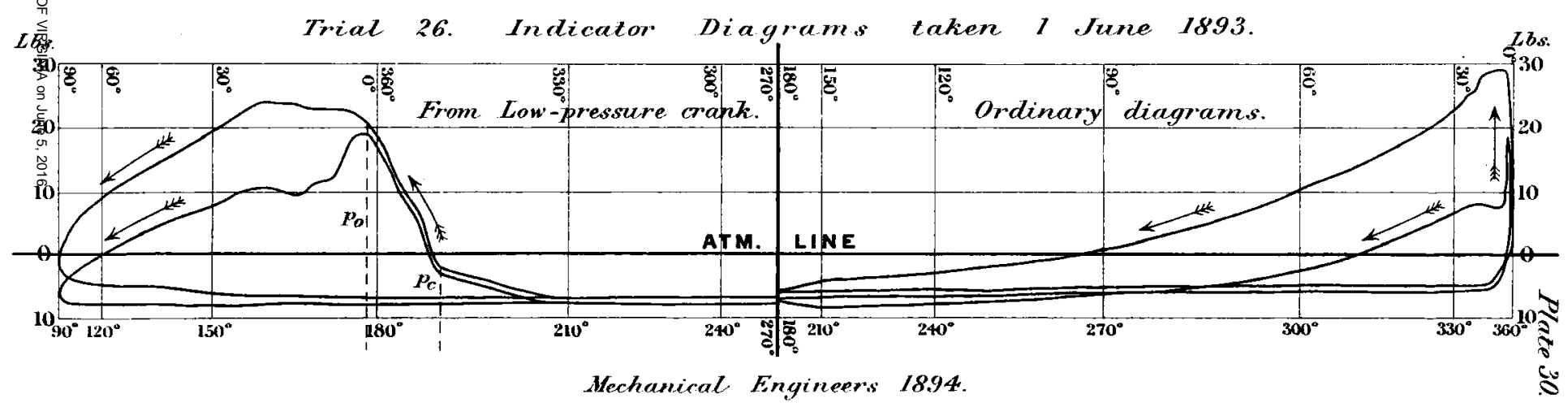


INITIAL CONDENSATION.

Condensation Temperature Curves, combined with Indicator Diagrams.

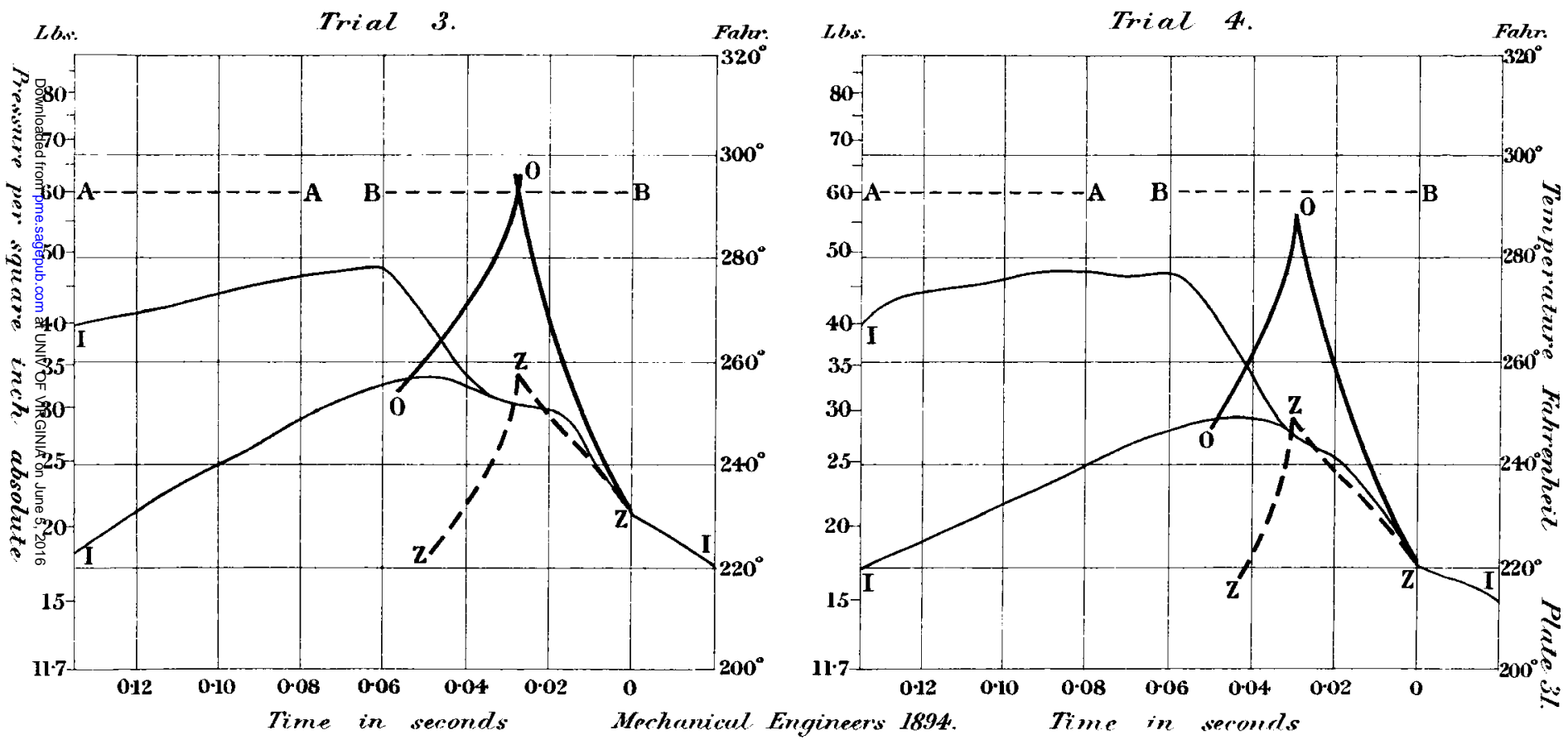




\section{INITIAL CONDENSATION.}

Condensation Temperature Curves, combined with Fudicator Diagrams.

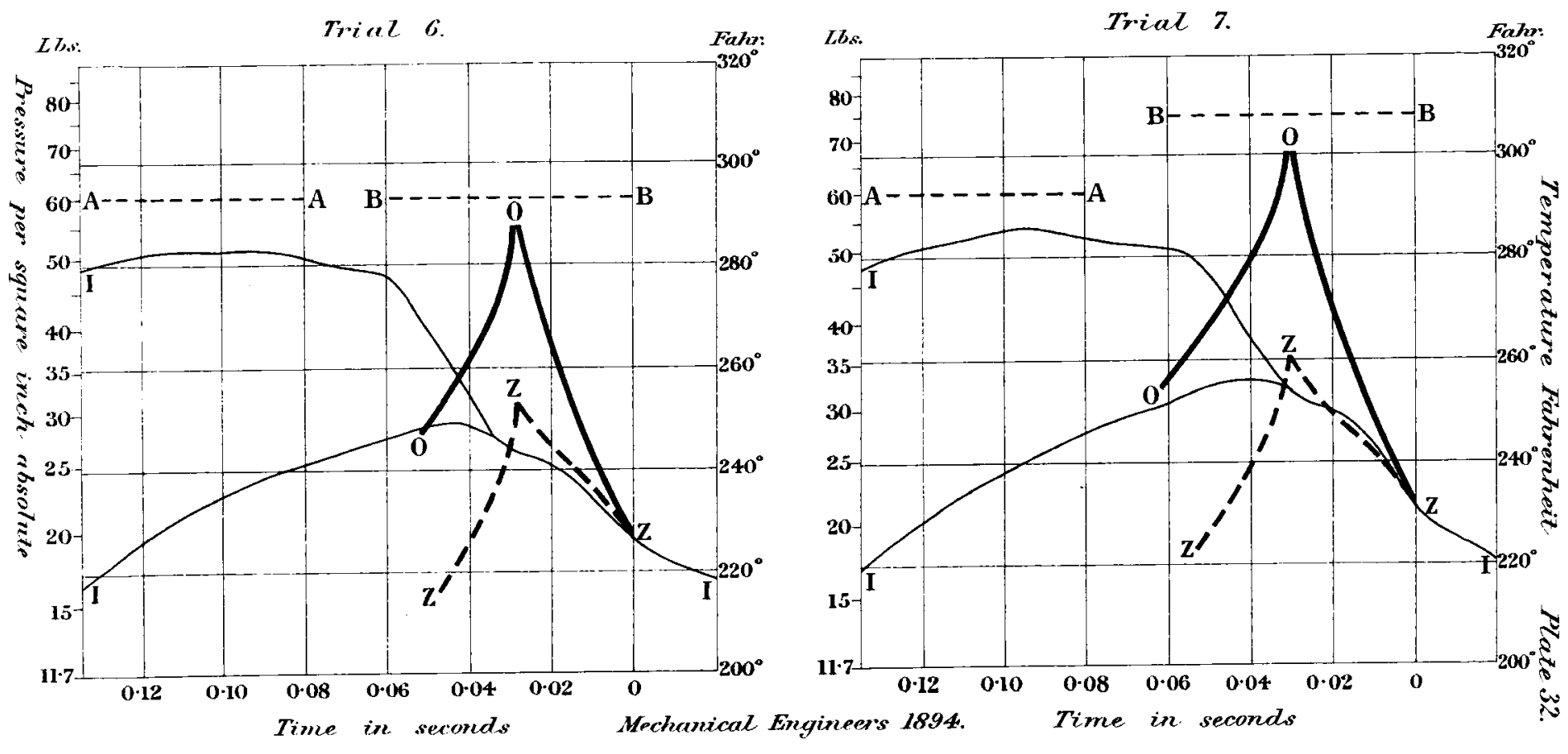

Downloaded from pme.sagepub.com at UNIV OF VIRGINIA on June 5, 2016 
INITIAL CONDENSATION.

Condensation Temperature Cumps, combined with Indicutor Diagrams.

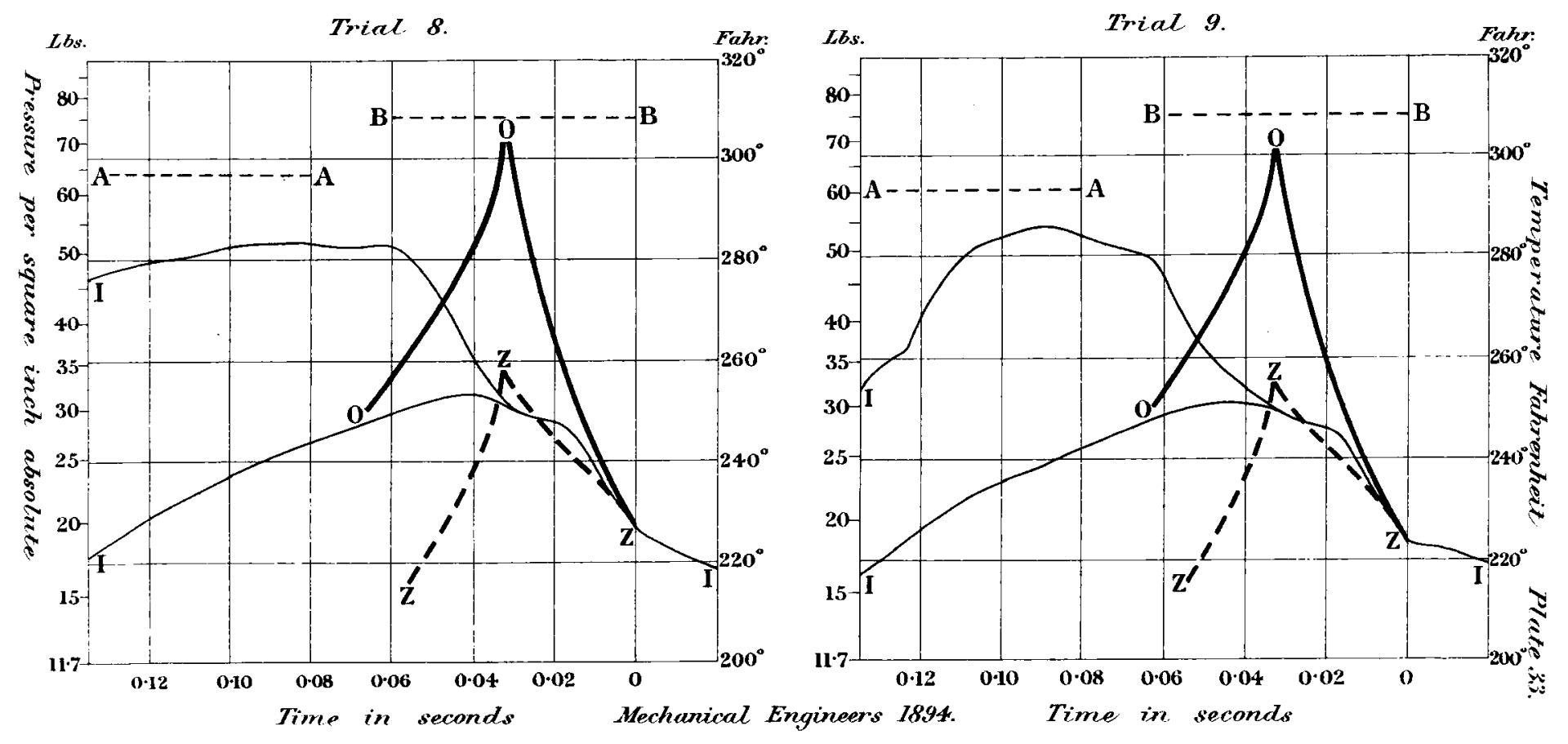

Downloaded from pme.sagepub.com at UNIV OF VIRGINIA on June 5, 2016 
INITIAL CONDENSATION.

Plaze 34.

Condensation Temperature Curves, combined with Indicator Diagrams.

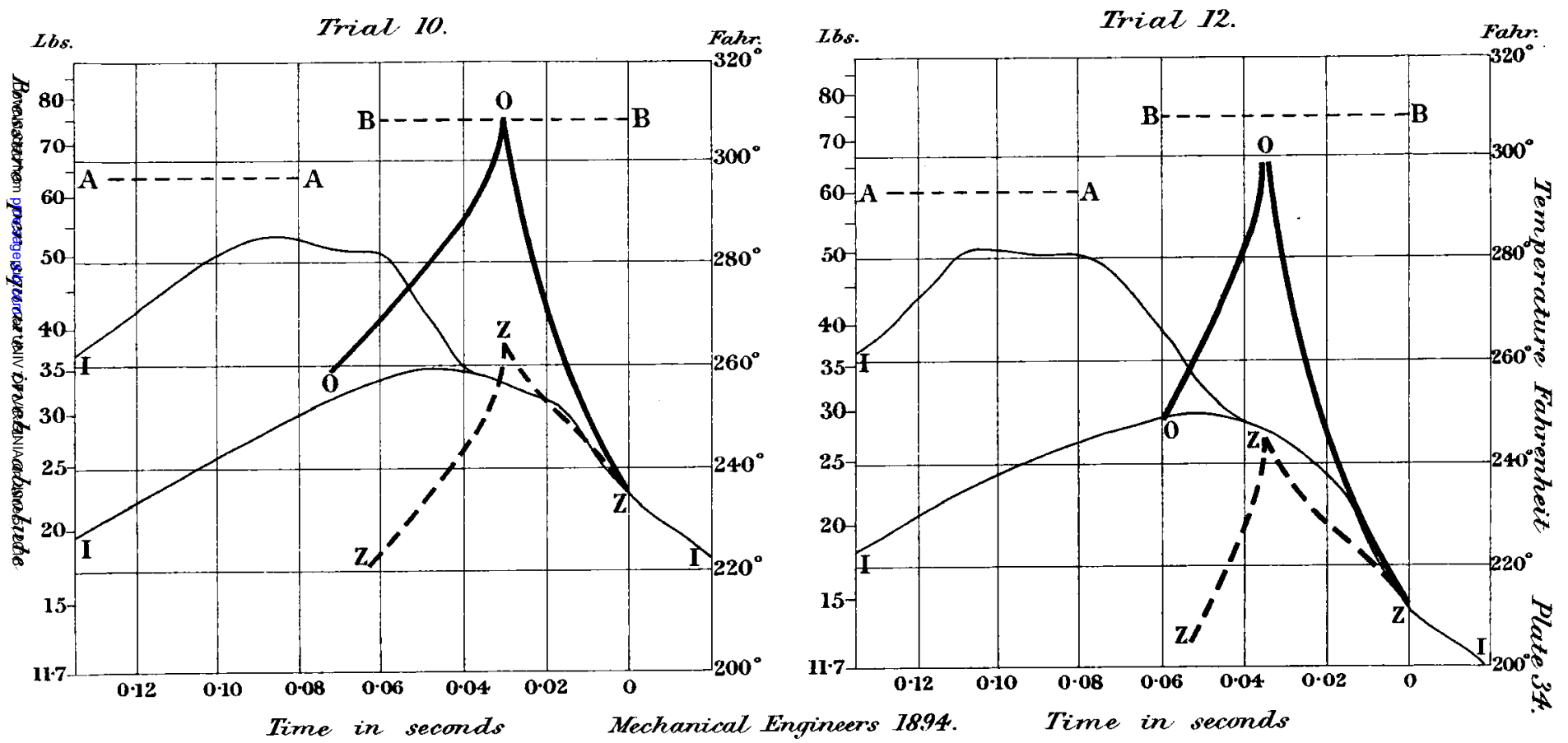


INITIAL CONDENSATION.

Condensazion Temperature Cumves, combined with Indicator Diagrams.

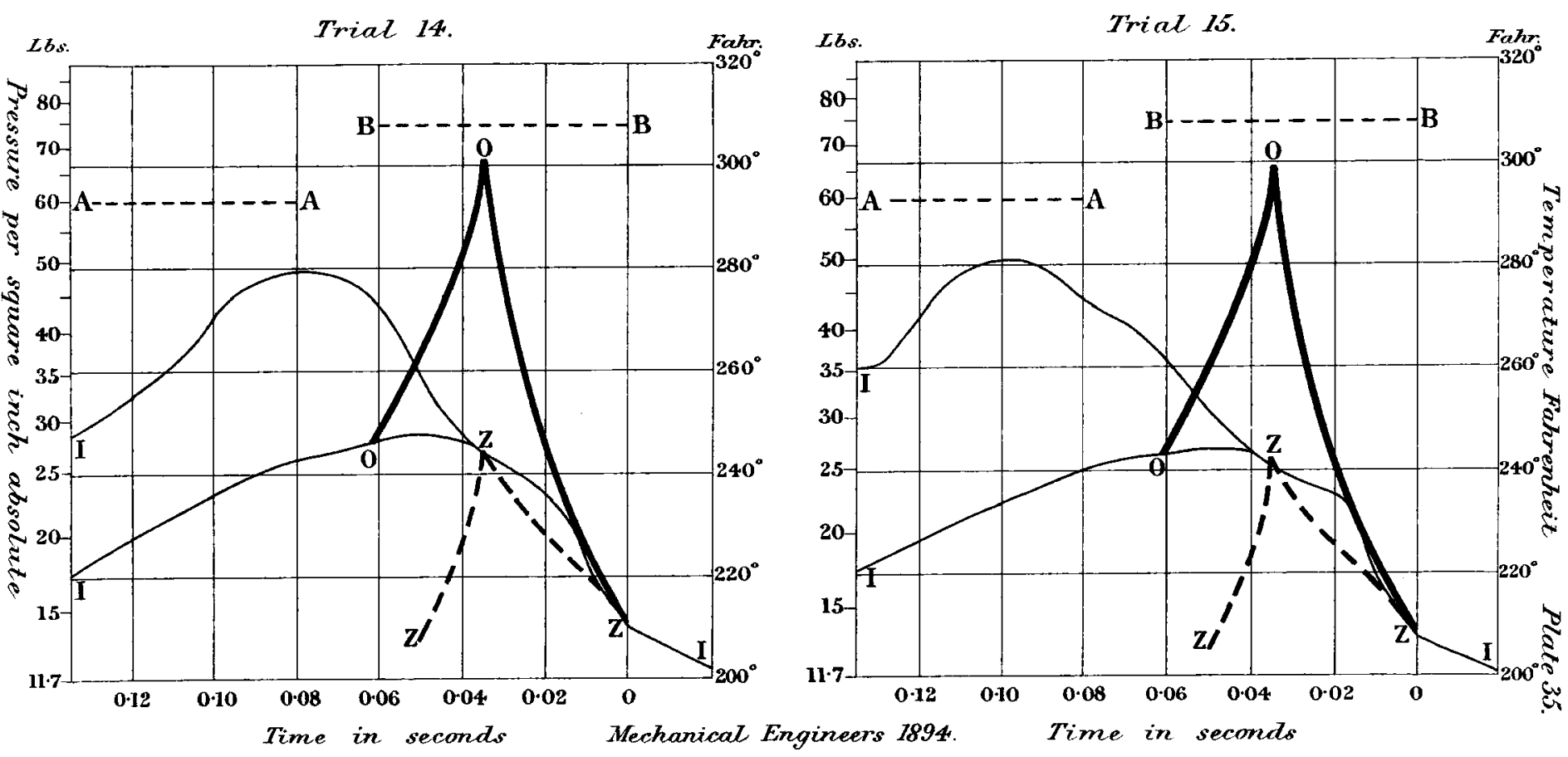

Downloaded from pme.sagepub.com at UNIV OF VIRGINIA on June 5, 2016 
INITIAL CONDENSATION.

Condensation Temperature Curves, combined with Indicator Diagrams.

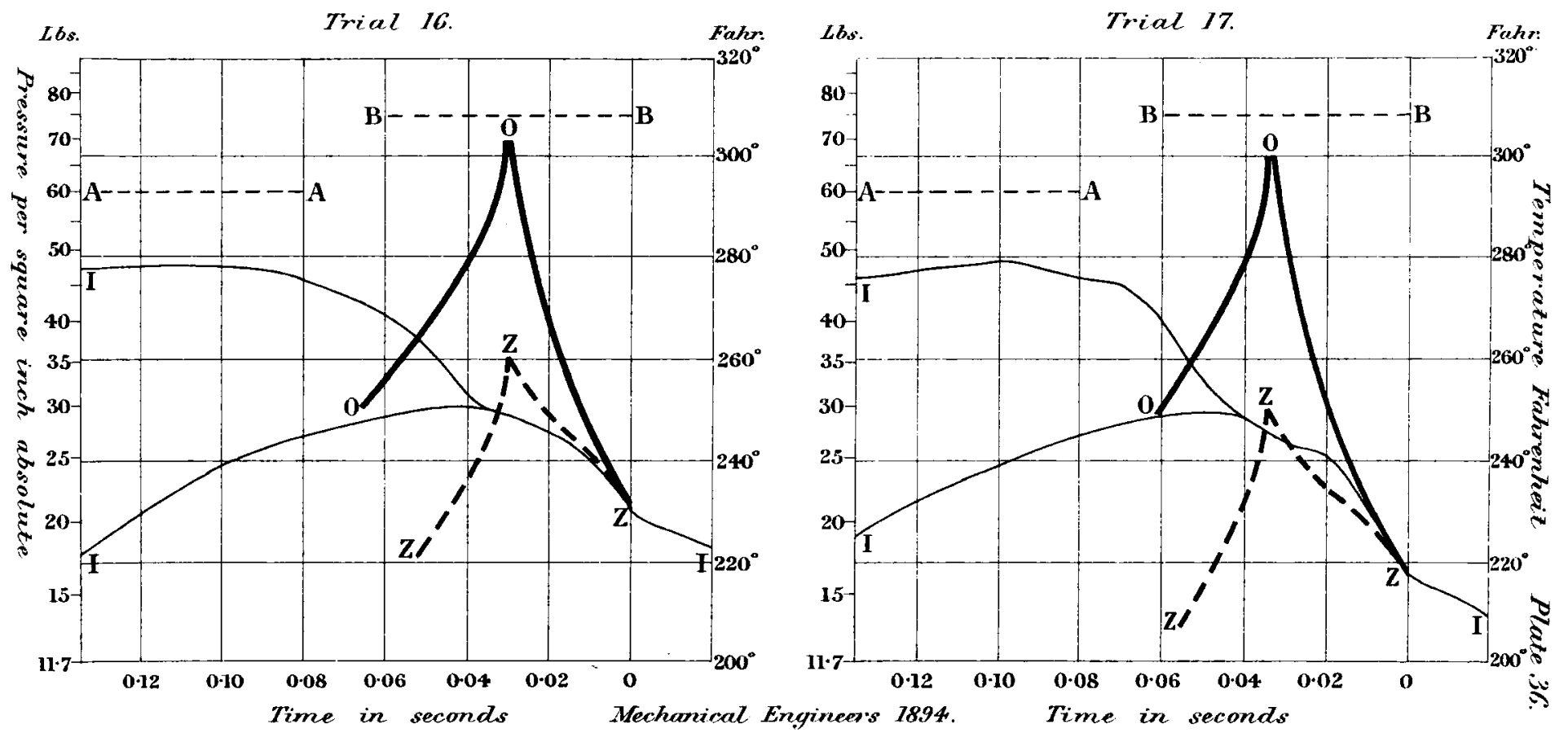


Condersation Temperature $L b s$. Trial 18.

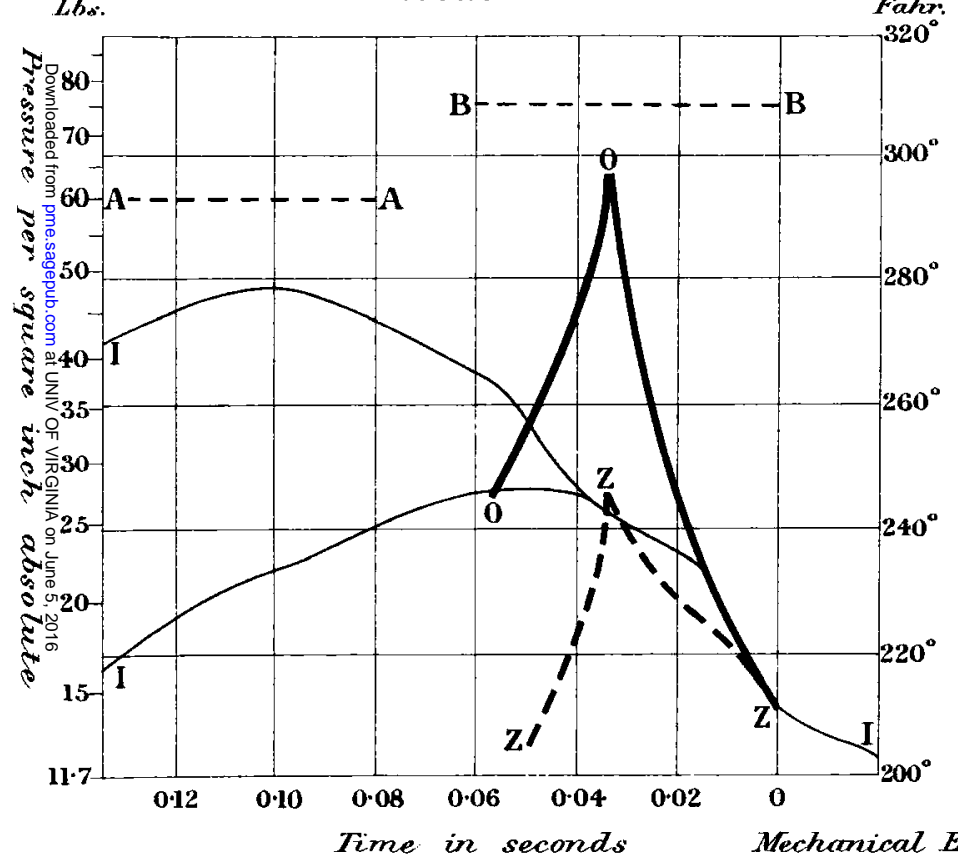

Time in seconds combined with

Lbs.

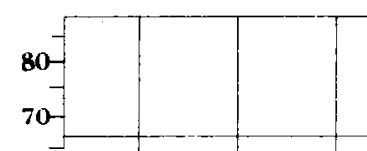

Trial 22.

Indicator Diagrams.

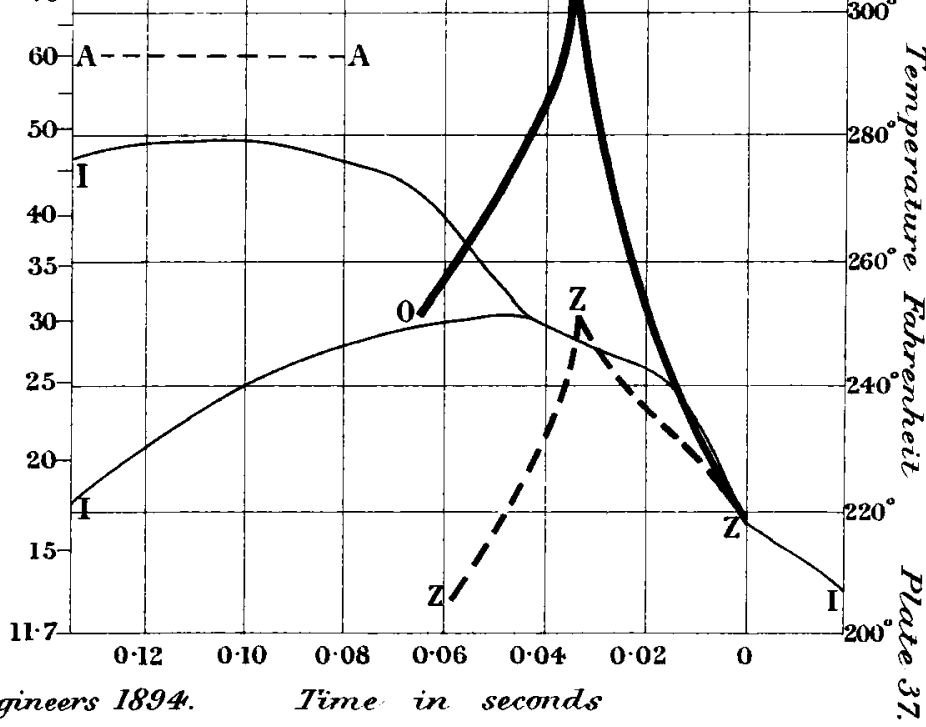
Falir: $320^{\circ}$

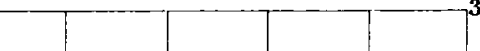


INITIAL CONDENSATION.

Condensation Temperature Curves, combined with Indicator Diagrams.

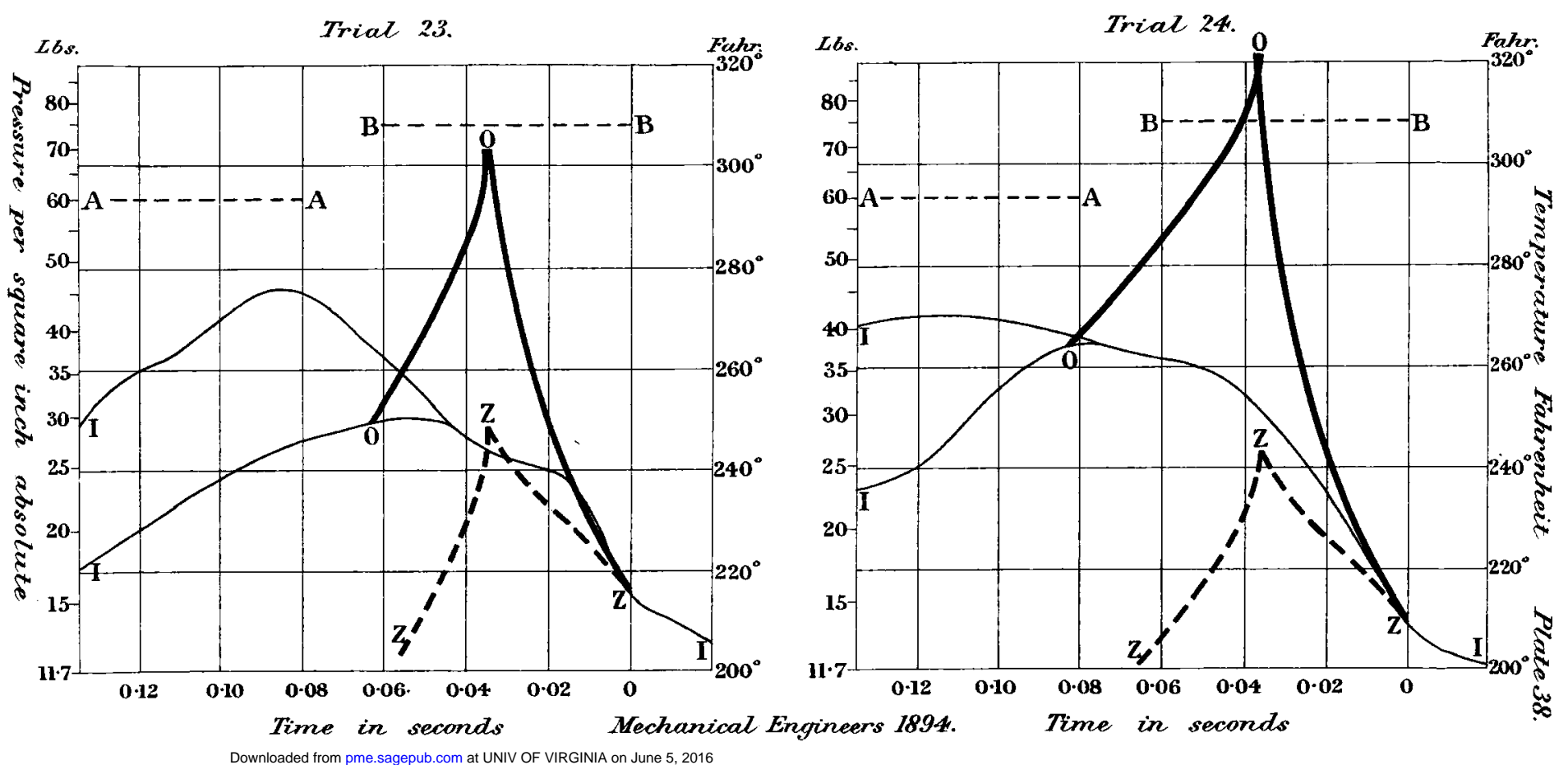


Condensation Temperature Curves, combined with Indicator Diagrams.
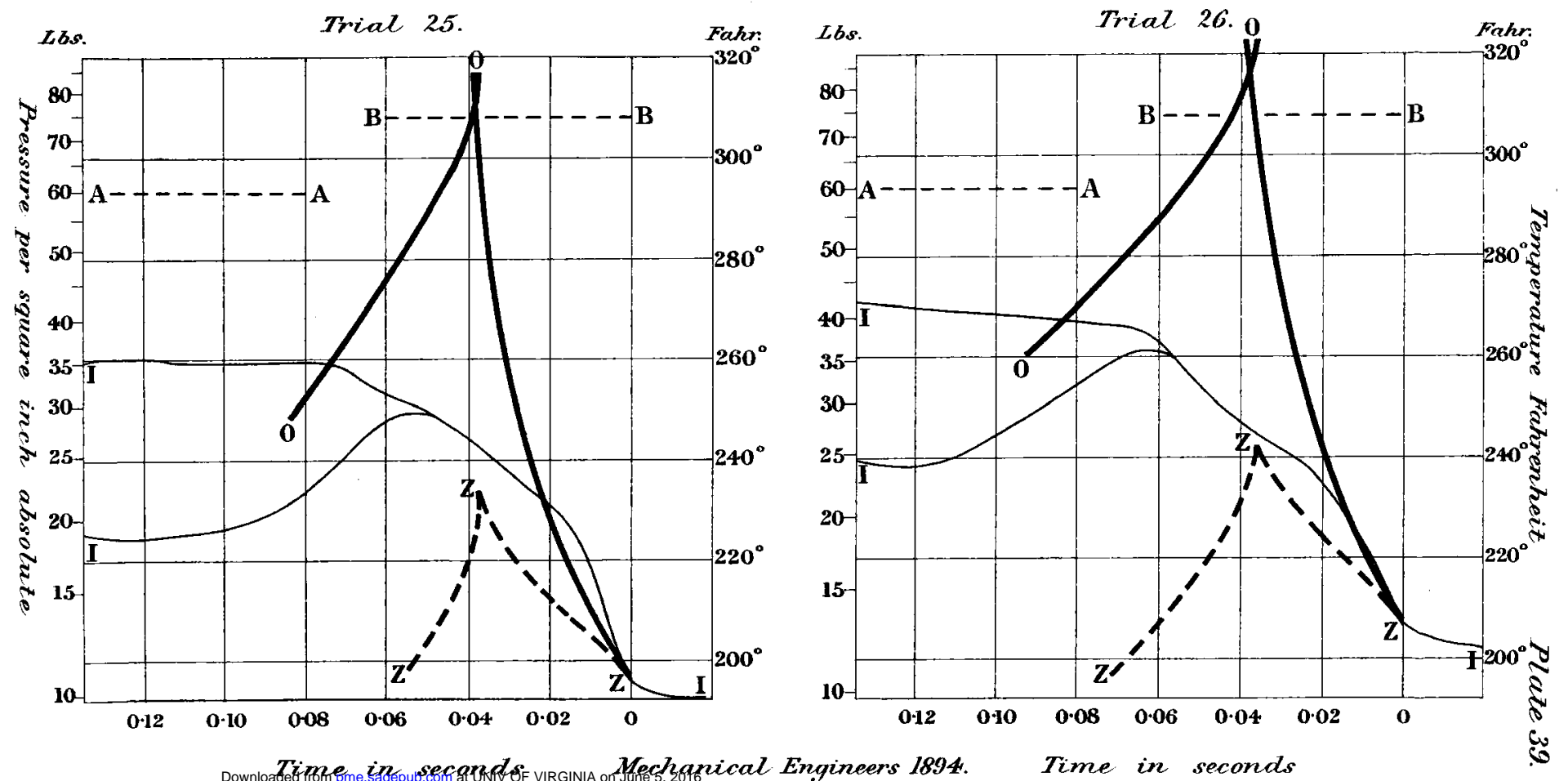

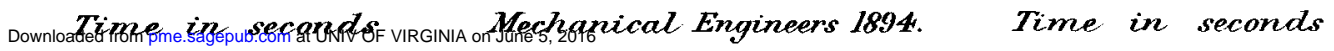


Transmission of Heut from Steam-Jacket

through last-Iron Cylinder-Liners of varying thickness. Pourds of Water evaporated per square foot per hour

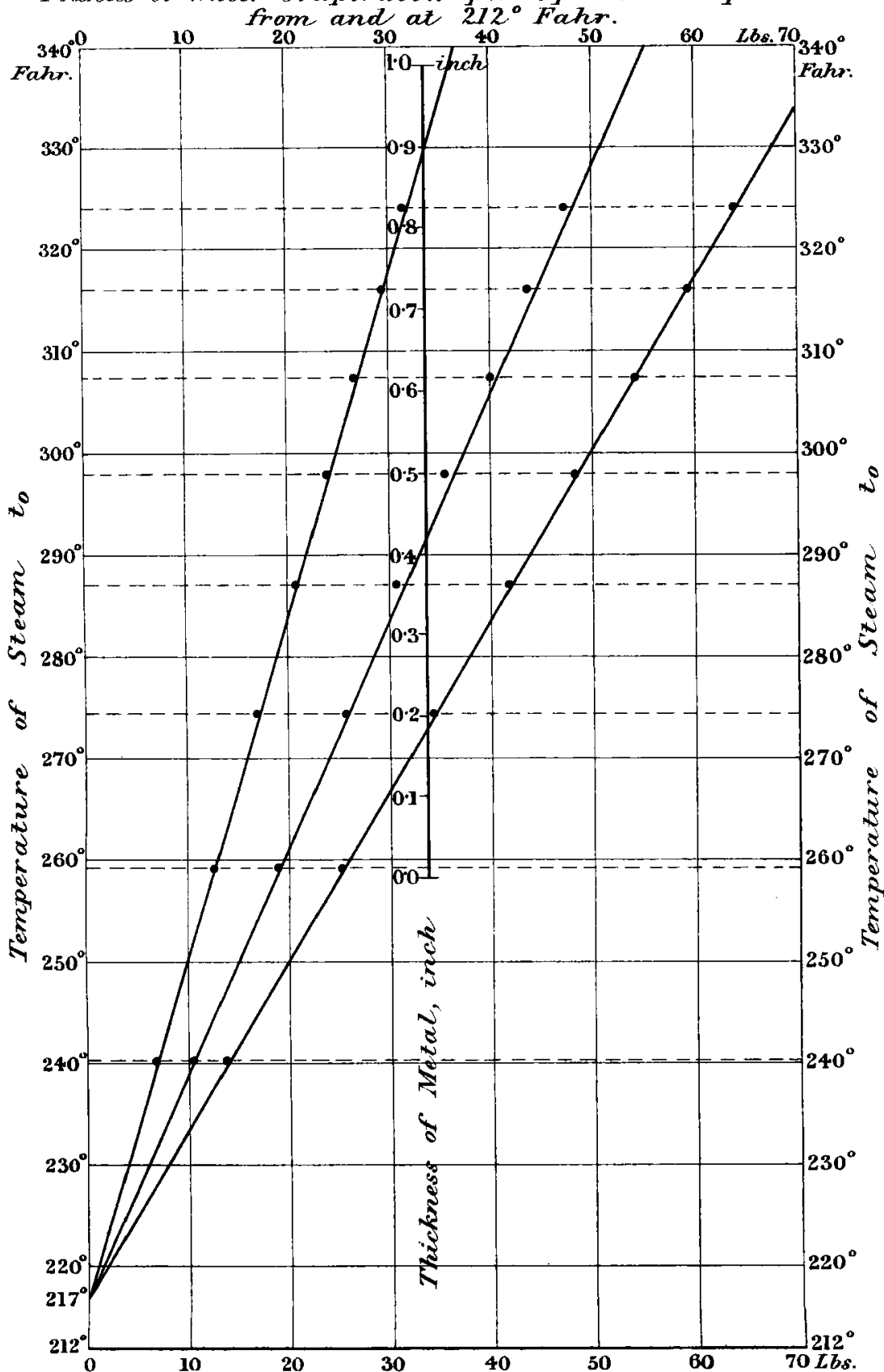

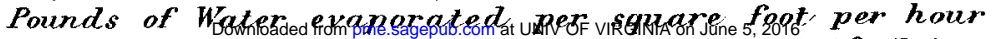
Mechanical Engineers 18.94. frorn and at $212^{\circ}$ Faher. 